University of Louisville ThinkIR: The University of Louisville's Institutional Repository

Electronic Theses and Dissertations

$5-2016$

\title{
Comparison of physical activity and sleep measures based on subjective and objective measures.
}

Amy Jo Walden

University of Louisville

Follow this and additional works at: https://ir.library.louisville.edu/etd

Part of the Sports Studies Commons

\section{Recommended Citation}

Walden, Amy Jo, "Comparison of physical activity and sleep measures based on subjective and objective measures." (2016). Electronic Theses and Dissertations. Paper 2387.

https://doi.org/10.18297/etd/2387

This Master's Thesis is brought to you for free and open access by ThinkIR: The University of Louisville's Institutional Repository. It has been accepted for inclusion in Electronic Theses and Dissertations by an authorized administrator of ThinkIR: The University of Louisville's Institutional Repository. This title appears here courtesy of the author, who has retained all other copyrights. For more information, please contact thinkir@louisville.edu. 


\title{
COMPARISION OF PHYSICAL ACTIVITY AND SLEEP MEASURES BASED ON SUBJECTIVE AND OBJECTIVE MEASURES
}

By

\author{
Amy Jo Walden \\ B.S., University of Louisville, 2014

\begin{abstract}
A Thesis
Submitted to the Faculty of the

College of Education and Human Development of the University of Louisville

In Partial Fulfillment of the Requirements

For the Degree of
\end{abstract}

Master of Science in Exercise Physiology

Department of Health and Sports Science

University of Louisville

Louisville, Kentucky

May 2016 



\title{
COMPARISION OF PHYSICAL ACTIVITY AND SLEEP MEASURES BASED ON SUBJECTIVE AND OBJECTIVE MEASURES
}

\author{
By
}

Amy Jo Walden

B.S., University of Louisville, 2014

A Thesis Approved on

$03 / 25 / 2016$

By the Following Thesis Committee

Kathleen Carter (Thesis Director)

Brock Symons

Marion Hambrick

Katie Synder

Daniela Terson de Paleville 


\section{ACKNOWLEDGEMENTS}

To my thesis advisor, Dr. Carter: you have helped me develop as a researcher and challenged me to critically critique my work as a professional researcher. Your time and patience developing this thesis and ensuring me everything would work out is far appreciated. I would like to thank the thesis committee for their effort in reviewing my work and for the crucial feedback. Thank you to the Male Field Hockey High School Team. This research project would not have been possible without your participation and cooperation throughout this process. Lastly, to my fellow thesis partner Alex, who was there for the entire process and ensured me all would work out in the end. 


\begin{abstract}
COMPARISION OF PHYSICAL ACTIVITY AND SLEEP MEASURES BASED ON SUBJECTIVE AND OBJECTIVE MEASURES
\end{abstract}

Amy J. Walden

March $25^{\text {th }}, 2016$

Sleep times and patterns are related to sport performance. Previous research suggests that sleep patterns contribute to differences in laboratory maximal effort treadmill tests, but little research has been done on maximal effort testing in the field. Further, research is lacking on whether sprint and acceleration times are correlated to sleep patterns.

PURPOSE: The purpose of this study is to determine if a relationship exists between field performance testing and sleep patterns in female high school field hockey players. METHODS: Within the first week of pre-season training female high school field hockey players $(n=15$, age $=15.47 \pm 1.06)$ completed a demographic survey, Pittsburgh Sleep Quality Index (PSQI) scale, and a seven-day sleep-wake journal using an online survey platform (Qualtrics, Provo, UT). Sleep latency, overall sleep quality, and duration of sleep were three PSQI measures chosen for analysis. The onset of sleep time and concentration were two measures used from the sleep-wake journal for analysis. A beep test and six $40 \mathrm{~m}$ sprints with $10 \mathrm{~m}$ splits were conducted within the first week of preseason training, with 48 hours between each test. Beep test was a $20 \mathrm{~m}$ multistage test that 
involved running in accordance to a pre-recording of beeps. Field tests were conducted on a level grass field under research supervision. An average of six $40 \mathrm{~m}$ sprints and $10 \mathrm{~m}$ splits were taken for analysis. RESULTS: PSQI revealed no participants suffered from sleep disorders. A Pearson correlation was conducted between performance and sleep pattern variables. A positive strong correlation exists between $40 \mathrm{~m}$ average sprint time and $10 \mathrm{~m}$ average sprint time $(r=0.896, p \leq 0.05)$. A negative correlation exists between onset of sleep and total sleep time $(r=-0.598, p \leq 0.01)$. There were no correlations between performance and sleep pattern variables. CONCLUSION: These results indicate maximal effort field-testing does not correlate with sleep patterns in female high school field hockey players. 


\section{TABLE OF CONTENTS}

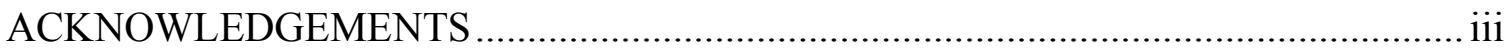

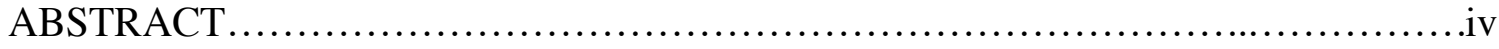

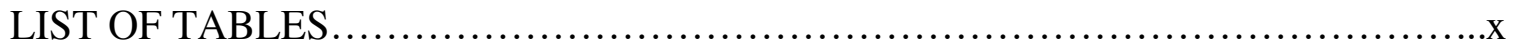

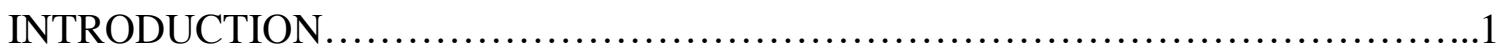

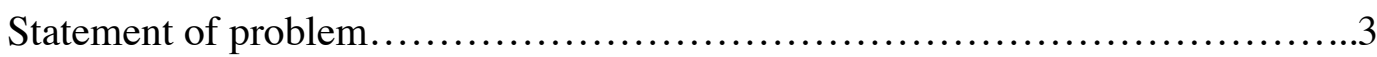

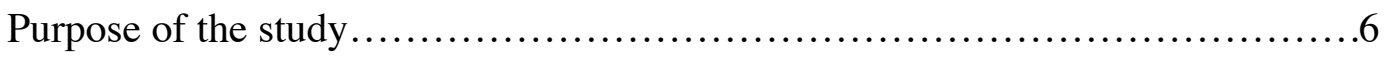

Research Questions \& Hypotheses........................................6

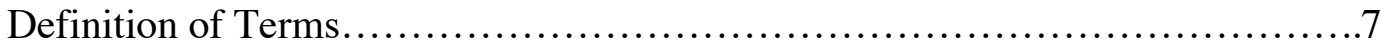

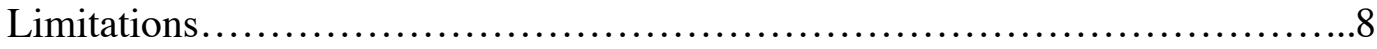

Delimitations............................................................ 9

Assumptions............................................................

Ethical Considerations................................................... 10

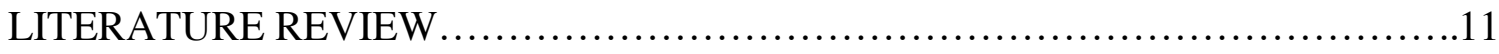

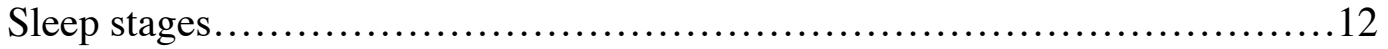

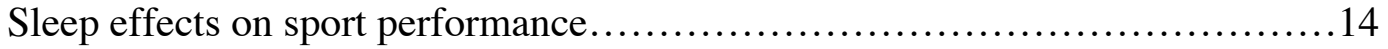

Effects of sleep deprivation on physical performance..........................15

Effects of sleep elongation................................................ 16

Measurements.............................................................. 17

Literature Review Conclusion..................................................

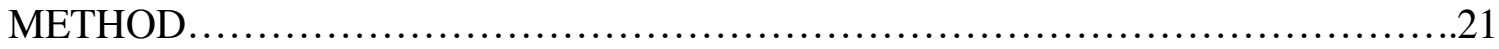


Participants.........................................................21

Objective testing- validation.........................................23

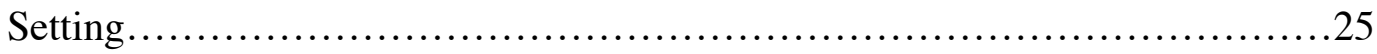

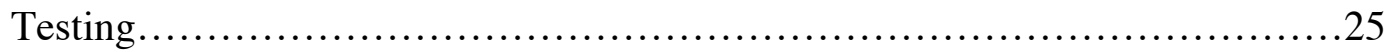

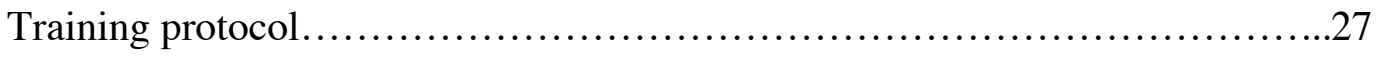

Research design...................................................27

Statistical Analysis.....................................................29

Sample size calculation............................................29

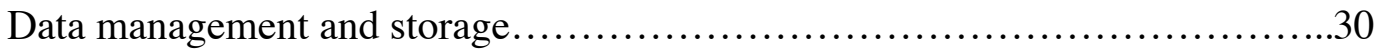

RESULTS............................................................... 31

Accelometer validation............................................... 31

Questionnaires.................................................... 33

Sports performance............................................... 34

Correlations between sleep and sport performance.........................35

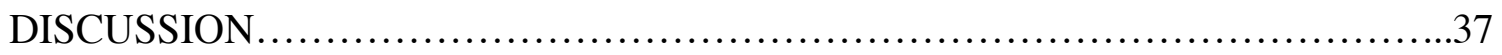

Performance implications.......................................... 38

Study limitations.................................................. 39

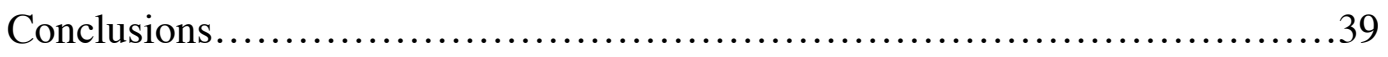

Future research directions...........................................41

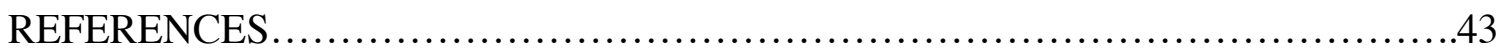

APPENDIX A: Pittsburgh Sleep Quality Index Questionnaire $\ldots . \ldots \ldots \ldots \ldots \ldots \ldots \ldots \ldots . . .48$

APPENDIX B: Sleep-Wake Journal.......................................53

APPENDIX C: Accelerometer Testing ......................................62

APPENDIX D: Self-administered Scale for Pubertal Development...................64

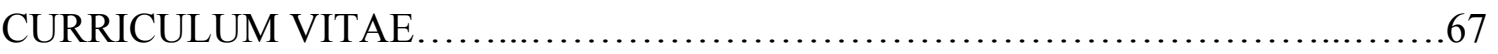




\section{LIST OF TABLES}

TABLE $\quad$ PAGE

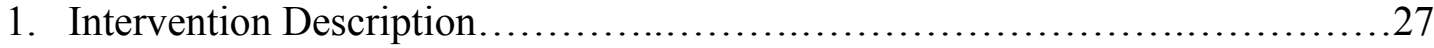

2. Accelerometer Validation Measurements..........................................31

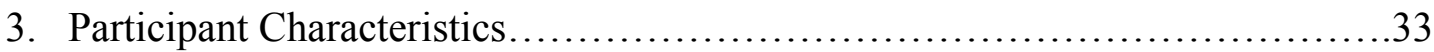

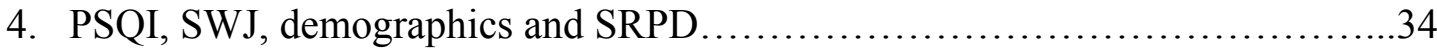

5. Performance Testing: Beep test and $10 \mathrm{~m} / 40 \mathrm{~m}$ average sprint time (secs)........34

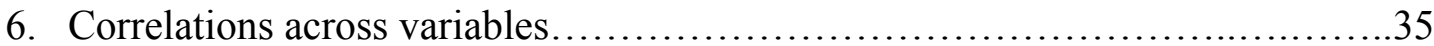




\section{LIST OF FIGURES}

FIGURE PAGE

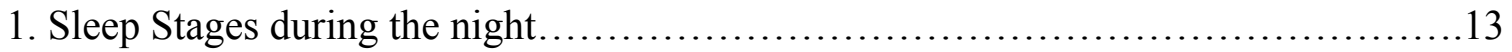




\section{INTRODUCTION}

Children and adolescents have seen an increase in stress as they complete rigorous school programs, participate in school club activities, and complete community service in order to excel on a college application (Pope \& Simon, 2005). As tension increases in adolescents, rates of depression and general fatigue increase, further promoting the adolescent to deprive himself or herself of sleep (Scott, McNaughton \& Polman, 2004). Sleep is seen as a crucial piece of growth and development, especially in developing adolescents. Participants who report a decrease in total sleep time and increase in sleep latency $(n=1,941)$ display poorer school performance and symptoms of insomnia (Ming, Koransky, Kang, Buchman, Sarris, \& Wagner, 2011). This problem is further exacerbated in adolescent athletes who feel the pressure to excel in their sport.

Sleep is a vital part of our daily life. Sleep is necessary to decrease subjective sleepiness, improve task performance, and fill nighttime hours. Athletes sleep in an effort to increase performance and decrease muscle fatigue (Halson, 2013). Sleep is reported to be the number one modality for recovery in both male and female athletes (Halson, 2008). Based on previous research, there is an increase in sleep need for athletes and

adolescents due to the maturation process. In a study conducted on young adults (ages 18-32) and older adults (ages 60-75), young adults reported later bed times and later 
wake-up times. The older adults showed a significant decrease in total sleep time $(p<0.001)$ by an average of 54.1 minutes per night when measured over a seven day period compared to young adults. Young adults reported more napping times in comparison to older adults (Yoon, Kripke, Youngstedt, \& Elliott, 2003). This finding could be attributed to the restitution theory where adolescents release higher amounts of hormones during puberty. In a separate study conducted on high school students $(n=2,147)$ students reported an increase in sleep efficiency and total sleep time on weekends in comparison to weekdays. On weekdays adolescents reported $80 \%$ of students arose before 7:00 AM. On weekends adolescents reported $0.2 \%$ arose before 7:00 AM (Ming et al., 2011).

Previous studies suggest adolescents need nine hours on average of sleep each night for adequate recovery, decrease episodes of depressive moods, and prevent sleep/wake behavior problems (Ming et al, 2011; Wolfson \& Carskadon, 1998). Sleep in athletes has not been heavily researched in order to determine an appropriate amount of sleep time for all sports. However, most researchers agree adolescents and young adults need an average of eight to ten hours of sleep per night for optimal function. Research indicates total sleep time is determined by intensity, duration, and frequency of exercise bouts (Miki, \& Yoshimoto, 2012; Shapiro, 1981). Individuals in ultra-distance events may need to sleep longer than individuals at moderate intensity exercise programs due to muscle inflammation and morphological skeletal muscles. Ultra endurance athletes have an increased number of inflammation cells with macrophages being the predominant cell type that accounted for this inflammation as muscle repair occurred. The morphological changes that occurred were observed in the damaged oxidative fibers containing the 
highest markers for mitochondria. The type 1 muscle fibers appeared ragged and signs of muscle repair were noted 28 hours post exercise (Marklund, Mattsson, Wahlin-Larsson, Ponsot, Lindvall, Lindvall, \& Rad, 2013). Ming et al. (2011) and Mah, Mah, Kerzirian and Dement (2011) determined sleep elongation for basketball athletes decreased participants' sprint times 0.7 seconds from pre-test $(\mathrm{P}<0.001)$, reaction times improved, and levels of daytime sleepiness were decreased.

Few studies address the effect of sleep on sports performance in a naturalistic environment, in which sleep can vary nightly based on daily commitments. Additionally, there are very few longitudinal studies addressing sleep patterns on sport performance in adolescent athletes.

\section{Statement of the Problem}

Research in the field of sleep studies on athletic performance is lacking. According to Thun, Bjorvatn, Flo, Harris and Pallesen, as of November 2013 there were only 116 articles published on the topic of sleep, training schedules and athletic performance (2015). Of those 116 articles, 15 articles focus on maximal effort aerobic performance and 30 focused on anaerobic power performance in lab. All aerobic and anaerobic performance studies focused on laboratory maximal effort testing and there was no research conducted on the correlation of sleep measures in maximal effort field-testing. Further, these studies were not sport-specific to the athletic population and a sportspecific test was not used. Finally, testing on adolescent athletes has been limited, due to this group being a protected class.

Laboratory maximal testing is easier to control, which may be why the majority of studies have used laboratory settings. The results from Reilly, Waterhouse and Atkinson 
(1997) and Atkinson and Reilly (1996) suggest laboratory-testing time to exhaustion can be monitored through heart rate data and core body temperature. In both studies the laboratory test was conducted in a warm environment, where the temperature was not able to fluctuate daily. Field-testing environment is often unable to be controlled. Coaching staff of adolescent athletes may not have access to the heart rate or body temperature equipment that is possible in laboratory studies. Therefore, the field maximal effort testing is based on a subjective report from the athlete. Subjective measures from field test have also been validated in many studies. In a study conducted by Mah, eleven basketball players (19.4 \pm 10.4 years) extended their sleep schedule by two hours every night for two weeks to determine the effects of sprint times on sleep extension (Mah et al, 2011). Mah found sleep extension decreases sprint times by $0.7 \pm 0.08$ seconds between pre-sleep extension and post-sleep extension times. Testing was conducted on a NCAA basketball court that athletes practice on during their season. Daros and his team validated the beep test for use in predicting maximal oxygen uptake in field-based study (Daros, Osiecki, Dourado, Stanganelli, Fornaziero and Osiecki, 2012). Twenty-four soccer athletes (16.66 \pm 1.49 years) completed the maximal treadmill test and the beep test. A high correlation was found between maximal treadmill test and beep test $(r=0.768$, $p<0.000)$. However, there have been limited longitudinal studies conducted in fieldtesting on sleep measures and sport performance. This study is meant to fill that research gap.

Continuing, researchers can make the field testing specific to the individual sport that is tested. Of the studies mentioned above, seven studies made efforts to be sport-specific. Swimming speed and swim bench were used to determine sleep effects on anaerobic 
performance in the morning and afternoon (Baxter \& Reilly, 1983 and Kline, Durstine, Davis, Moore, Devlin, Zielinski et al, 2007). Fourteen competitive swimmers (14.7 years) completed a 100m, $400 \mathrm{~m}$ and front crawl swim. Each athlete completed tests at 9:00, 13:30, 17:00 and 22:00 hours. The results determined fastest swimming times were recorded for $100 \mathrm{~m}$ at $6: 30 \mathrm{~h}$ and fastest $400 \mathrm{~m}$ at 22:00 h (Baxter \& Reilly, 1983). A separate study completed on 11 NCAA basketball players (19.4 \pm 1.4 years) recorded time sprints following a two-week sleep extension period. Timed sprints in basketball consisted of a sprint from baseline to half-court and back then to full court and back to baseline (Mah et al, 2011). The results indicated a sleep extension period of two hours decreased sprint times and increased shooting accuracy. These sprints are typical of a sprint that would be performed in a basketball game situation. In the current study, $40 \mathrm{~m}$ sprints are used to stimulate game-like situation for testing, as $40 \mathrm{~m}$ is a typical distance an athlete would sprint in field hockey (Lythe \&Kilding, 2011).

Research into adolescents' sleep patterns centers heavily on school start times, with few studies focused sleep effects on sports involvement during adolescence. A comprehensive review of adolescent sleep patterns conducted by Crowley, Acedbo and Carskadon determined that extra-curricular activities, such as sports, could contribute to changes in bedtime; however further research is needed to determine the overall effect activities play on sleep (2007). Sleep/wake timing shifts typically occur throughout life, with a noticeable chance in adolescents. A clinical review on sleep changes in adolescence is detailed in Wolfson and Carskadon's work in school-age children, which as children age their sleep times become later and their wake times become earlier 
(2003). Wolfson further stated there are no longitudinal studies on adolescent sleep during the school breaks, as well as in conjunction with sport play (2003).

Given the previous body of research, the aim of this investigation was to fill the gaps in current knowledge relating to field-testing of adolescent athletes. Discovering what relationship, if any, exists between sleep patterns and performance in sports allows this gap to be filled. Additionally, by employing sport-specific field tests, this research study allows for coaches and trainers of adolescent athletes to better monitor their athletes' sleep patterns as it relates to sport performance.

\section{Purpose of the study}

The present study seeks to examine the effect of sleep measures on aerobic capacity, acceleration speed, and top-end speed in female field hockey athletes. Adolescent female field hockey players in the present study complete a seven-day sleep-wake journal, Pittsburgh Sleep Quality Index survey, beep test and 40m sprint data. The information produced within this study seeks to fill the gaps in the research between athletes' reported sleep measures and sport-specific field based testing. Not only does this affect the scope of sleep patterns in adolescent athletes, but it will also provide scientific evidence for field-testing in adolescent athletes.

\section{Research questions and Hypotheses}

1. Is there a correlation between sleep measures (such as onset of sleep, sleep latency, total sleep time, quality of sleep and concentration level) and performance measures in high school female field hockey athletes? Based upon the results seen in Mah et al., we expect that beep test scores, 
acceleration speed, and top-end speed will be increased in athletes who sleep at least 8 hours per night (2011). To recap, the study included 11 basketball players, who were tested on: sprint performance, shooting accuracy, reacting time and sleep-wake patterns. Participants were tested in the first 2 weeks on the study, in which sleep-wake patterns were not changed for any athlete. The athletes were then instructed to sleep 2 more hours every night for 2 weeks. The post testing occurred during the final 2 days of the sleep extension period. All athletes who slept the additional two hours demonstrated faster sprint times and improved shooting accuracy.

\section{Definition of terms}

For the purpose of this study, the following terms and their associated abbreviations are defined.

- The Pittsburgh Sleep Quality Index (PSQI) is a global sleep scale that is determined through a nineteen question assessment pertaining to sleep quality, sleep quantity, sleep latency, sleep efficiency, sleep disturbances, use of sleep medicines, and daytime dysfunction.

- Sleep latency (SL) is determined by the total minutes taken to fall asleep once subjects are in their beds, according to PSQI.

- Quality of sleep (QOS) is determined on a Likert scale of 1 (good) to 5 (poor), according to PSQI.

- Total Sleep Time (TST) is determined by minutes participants slept per night, according to the PSQI. 
- Sleep-wake journal (SWJ) is the four-day journal based on Mary A. Carksadon research that details sleep times, concentration levels, and quality of sleep.

- Onset of sleep (OS) is determined by the hour the subject fell asleep based on a scale, according to $\mathrm{SWJ}$ where before $10 \mathrm{p}=$ score of $1,10-11 \mathrm{p}=2,11 \mathrm{p}-12 \mathrm{a}=3$, $12-1 \mathrm{a}=4,1-2 \mathrm{a}=5$, past $2 \mathrm{a}=6$.

- Concentration is determined on a Likert scale of 1 (good) to 5 (poor) as the total concentration level the subject felt throughout the day, according to the SWJ.

- Self-administered rating scale for pubertal development (SRPD) is a self-reported Tanner rating scale that determines level of pubertal development throughout adolescent.

- Beep test is a $20 \mathrm{~m}$ multistage test that involves running in accordance to a prerecording of beeps. For the purpose of this study, aerobic capacity is determined through a beep test.

- $10 / 40 \mathrm{~m}$ sprints is a $40 \mathrm{~m}$ sprint that involves a subject sprinting from a start cone through a cone placed at a $40 \mathrm{~m}$ mark. A cone is placed at the $0 \mathrm{~m}, 10 \mathrm{~m}$ and $40 \mathrm{~m}$ mark and a stopwatch is used to collect sprint times at the $10 \mathrm{~m}$ and the $40 \mathrm{~m}$ mark.

- Acceleration speed is measured at $10 \mathrm{~m}$ taken from the $10 / 40 \mathrm{~m}$ sprints by time in seconds it takes the athlete to complete the sprint.

- Top end speed is measured at the $40 \mathrm{~m}$ taken from the $10 / 40 \mathrm{~m}$ sprint by time in seconds it takes the athlete to complete the sprint.

- Sleep has been defined as a discrete state and as being part of a continuous cyclical change in level of consciousness (Duxbury, 1994, pg. 26).

\section{Limitations}


The study is limited to female athletes, as we are only working with a female field hockey team. Therefore, no comparison can be made based on sex.

The sample size in the study is based on three field hockey teams that include a freshmen team, junior varsity team, and varsity team. Based on these teams varsity members may have an increased fitness level prior to beginning the program. Furthermore, there is no way to control for injuries. Therefore, participants who experience an injury and are not able to complete the study are removed from the sample and their data is not used in the result section.

\section{Delimitations}

The researchers have determined not to conduct a polysomnography overnight sleep assessment based on the cost of the procedure and specialist needed to provide an explanation of the data. Furthermore, polysomnography may not stabilize until the fourth consecutive day, which is measured by the adaptation of rapid eye movement sleep (Le Bon, Hoffmann, Dramaix, San Sebastian, Murphy, Kentos, et al., 2001); therefore, the PSQI was chosen to determine any sleep disorders present in the sample population.

\section{Assumptions}

It is assumed the participants answered the questionnaires truthfully. Anonymity through the study was maintained to encourage honesty from all participants. It is assumed that each athlete gave maximal efforts on all the performance tests.

\section{Ethical considerations}


The Institutional Review Board at University of Louisville approved this study. As participants were under the age of 18 , informed consent were obtained from parents of participants and assent forms were obtained from the participants. Informed assent was obtained from each participant prior to data collection. Kentucky high school athletic association policies and procedures regarding safety procedures were followed at all times. There were no foreseeable risks to individuals, beyond that of typical sport participation. During questionnaire completion participants were informed that could leave questions blank they did not feel comfortable disclosing. 


\section{LITERATURE REVIEW}

Research on sleep and sport performance has been confined to adults in laboratory settings. Laboratory tests are not sport-specific to field athletes and fail to provide a naturalistic environment that would mimic sports play. Literature on maximal fieldtesting, including the beep test, in relation to adolescent sleep patterns is limited, as most research around adolescent sleep patterns involve school start times. Finally, studies including female adolescent athletes and maximal field-testing for sport performance on sleep patterns using sleep diaries during pre-season training are missing from research. Therefore, it is the purpose of this review to provide information on this topic.

There is little research to determine the exact need for sleep; however, there are various theories that speculate why sleep is important for the body's repair system and chemical toxin removal. Three theories that will be discussed are the humoral theory, learning and memory theory, and the restitution theory. The humeral theory states that sleep is regulated by fluctuations in hormones. Researchers under this theory believe prostaglandins stimulate sleepiness (Urade and Hayaishi, 2011). The learning and memory theory hypothesizes that sleep promotes memory conversion from short-term to long-term memory. Researchers under this theory believe the rapid eye movement phase of sleep begins the consolidation process of short-term to long-term memory (Smith \& 
MacNeill, 1994). For this specific study, we are concerned only with the restitution theory. The restitution theory states that tissue repair and growth occurs during sleep. Evidence to support this claim comes from a variety of sources. During the sleep-wake cycle heart rate is lowered, blood pressure is lowered, cortisol peaks during sleep, sympathetic nervous control decreases, and hormones are released (Besedovsky, Lange, $\&$ Born, 2012). Of particular interest, growth hormones and prolactin are released during slow wave sleep (Takahashi, 1979; Besedovsky et al., 2012). Growth hormone functions primarily as an anabolic hormone that builds up muscle, increases protein synthesis, and promotes lipolysis. Prolactin functions primarily as a lactate letdown for pregnant women, dopamine receptor for all mammals, and provides a source for lymphocyte production (Freeman, Kanyiecska, Learnt, \& Nagy, 2000). Further evidence to support this theory comes from the body's decreased wound healing when in a state of sleep deprivation. Killer $\mathrm{T}$ cells decline during sleep deprivation impairing immune function (Moorcroft, 2013). A study conducted on rats $(n=50)$ determined that sleep deprivation delays wound healing and delays oxidative stress repair assed by pathological analysis (Gumustekin, Steven, Karabulut, Aktas, Gurson, Aslan, Koles,... Dane, 2004).

\section{Sleep stages}

First and foremost, the continuous cyclical change is attributed to the sleep-wake cycle, which consists of four stages. The stages rotate every 90 minutes and include rapid eye movement (REM) and non-REM sleep. REM sleep is characterized by muscle twitches, increase heart rate changes, and increased respiratory rate. Parasympathetic control is shown through lower voltage waves in electroencenphalogram (EEG), lack of muscular strength, and increased cortical activation (Turpin, 1986). Cortical activation 
waves are present in mental tasks and shown in sensory arousal, which further support the dreaming state and mental processing.

Non-REM sleep accounts for stage one, two, three, and four. Stage one sleep is considered the sleep state where an individual may be easier to awake or respond to outside stimuli and increased eye movement. During this sleep stage heart rate and blood pressure decrease as sympathetic control in the body is reduced. Stage two sleep consists of lack of eye movement and slower brain waves compared to stage one sleep. Stage three sleep sees a decline in response to outside stimuli and harder time waking. In stage four sleep no muscle activity is present at this time (Turpin, 1986). (Figure 1)

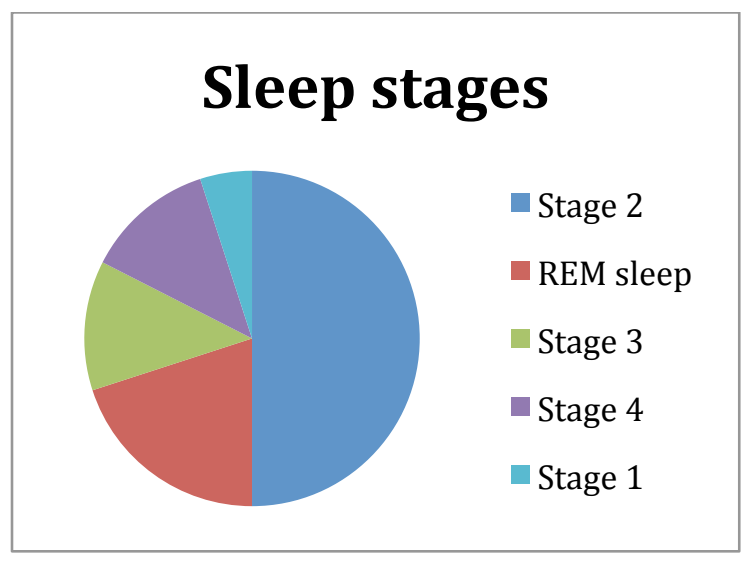

Figure 1. Sleep stages during the night. Sleep stages are broken up into amount of time spent at each stage during an 8-hour sleep time.2

Stage two sleep accounts for approximately $50 \%$ of total sleep time. REM sleep accounts for $20 \%$ of sleep time. Stages one, three, and four account for the remaining $30 \%$ of sleep time, with more contribution to the stage three and four sleep during deep sleep time periods. Stage one typically occurs during the first five to ten minutes of sleep, often reported as the closest measure of sleep latency (Hodgson, 1991).

\section{Sleep effects on sports performance}


Sleep effects on acute exercise are widely debated. Changes in sleep-wake patterns including total sleep time, sleep latency and nighttime wake times can occur; however, rate of change depends on intensity, duration, and mode of exercise, along with age and gender (Taylor, 2001). A study that compared low, moderate, and high intensity activity along with durations of 30,60 , and 90 minutes determined there was no effect on sleep quality or total sleep time. The only reported difference that occurred in the participants was a higher heart rate at rest the night following a longer duration of activity (Myllymaki, Rusko, Syvaoja, Juuti, Kinnunen, \& Kyrolainen, 2012). Longer exercise duration is hypothesized to cause increased total sleep time; however, no such result was reported following the study.

There are few studies that report changes in mode of intensity for sleep times and sleep quality. Endurance training is typically reviewed in research, as measures are easier to record. Treadmill and bicycle ergometer are most common in exercise testing (Crispim et al., 2007; Myllymaki et al, 2012; Youngstedt \& Kline, 2006). As previously noted, elderly adults tend to report more sleep problems as age increases compared to young adults. Research shows females tend to have a greater correlation between sleep and exercise, due to females typically having a reduced exercise capacity and an increased awareness of their subjective thoughts (Taylor, 2001). Conversely, when trained male and females are compared, there is no change between sleep times and reported sleep quality (Taylor, 2001).

Chronic exercise use in individuals leads to a decrease in sleep latency and an increase in sleep efficiency. Improved sleep measures have been associated with a stable physical activity program (Youngstedt et al, 2006). Individuals who report a constant 
sleep rate tend to adhere to physical activity programs and report lower stress rates in their daily lives. Individuals who reported sleep rates of eight hours of sleep per night weighed less than participants who slept less than six hours per night. Furthermore, particpants who slept at least eight hours a night and kept a consistent physical activity regime exhibited more protective factors against disease (Crispim et al, 2007).

\section{Effects of sleep deprivation on physical performance}

Sleep deprivation in individuals can result in a lack of muscle repair, increased levels of depression and anxiety, increased negative mood disturbances, and impairment in reaction times (Scott, McNaughton, \& Polman, 2004 and Fullagar, Skorski, Duffiled, Hammes, Couts \& Meyer, 2015). A study observing a thirty-hour sleep deprivation cycle increased subject fatigue, decreased subject vigor, and increased rates of depression as measured by the Profile of Mood States (POMS) survey. Participants were divided into a non-exercise group and an exercise group. The exercise group was required to exercise at moderate intensity on a cycle ergometer for twenty minutes every two hours. Neither group showed a difference in POMS scores. However, reaction time in the non-exercise group was significantly higher than the exercise group in computerized tracking tests, indicating participants who are sleep deprived and required to exercise may be at a higher risk of injury due to reduced reaction times (Scott et al, 2004). This response in the exercise group is due to increased sympathetic control, constant cerebral blood flow, and lack of hormone secretion that would be observed in REM sleep. During adequate sleep the cerebral blood flow is reduced in non-REM sleep to aid in reduction of metabolism. Hormone secretion is observed in slow wave sleep, where growth hormone, thyroid hormones, and melatonin secretion take place. Finally a decrease in sympathetic control 
during non-REM sleep allows the body to properly rest and heart rate to drop (Institute of Medicine, 2006). These physiological interactions are all important in maintaining rest, increasing learning, and maintaining proper hormone control. This interaction can be used as evidence to back up all major theories for sleep need.

Chronic effects of sleep deprivation are difficult to obtain due to longitudinal study design. A four week study followed rats exercising Monday through Friday for two fifteen minute sessions for weeks one and two, three fifteen minute sessions for week three, and four fifteen minute sessions at week four. Rats were separated into four groups: sedentary control, exercise control, sedentary 24-hour sleep deprivation, and exercise 24hour sleep deprivation. Results indicated that regular exercise could prevent fatigue even when sleep was not obtained for 24 hours. Exercise sleep deprivation rats were able to complete tasks at the same rate as sedentary control and exercise control rats. In both exercise control and exercise sleep deprivation short-term memory improved following exercise and increased energy was observed following each exercise bout (Zagaar, Alhaider, Dao Levine, Alkarawi, Alzubaidy, \& Alkadhi, 2011). Although exercise during chronic sleep deprivation can improve cognitive function, chronic sleep deprivation can cause insomnia and lead to depressive states. Lack of the body's repair system, cognitive rest during sleep, and increased anxiety all contribute to this finding (Lopresti, Hood, \& Drummond, 2013).

\section{Effects of sleep elongation}

On the other hand, sleep elongation can have positive effects on a subject's cognitive levels, muscle recovery, and performance scores. Eleven Stanford University men's varsity basketball players were recruited for a study that aimed at comparing normal 
sleep during a 2 to 4 week baseline ( $400.7 \pm 61.8 \mathrm{~min})$ to a 5 to 7 week sleep extension period (507.6 \pm 78.6$)$ to investigate if sport performance increased with total sleep times. Sport performance was tested using a 282 foot sprint, 3-point shooting accuracy from 15 attempts and free-throw accuracy from 10 attempts. The study found participants' shooting accuracy, free throw percentage increased by $9 \%$ and 3-point field percentages increased by $9.2 \%$ were increased from pretest during the sleep extension period $(\mathrm{P}<0.001)$. Acutely sleep elongation on exercise bouts seems to increase performance and reduce fatigue (Ming et al, 2011, and Mah et al., 2011).

It is interesting to note chronic excess sleep can play a role in depressive states; however, this interaction typically occurs only when the individual is using sleep to avoid responsibilities (Lopresti et al., 2013). Elongation sleep without avoiding responsibilities does not correlate with higher rates of anxiety or depression. Further proof of the effects of sleep comes when insomnia interventions are used to increase sleep time and depressive scores as indicated by POMS drop significantly. In fact, increased sleep in the general population is noted to provide protective benefits against metabolic disorders. This is due to the decrease of leptin and increase in ghrelin levels in sleep deprived states that create a hunger sensation (Crispium et al., 2007).

\section{Measurements}

Sleep quality is measured subjectively through a variety of self-reports and scales. The two tests most commonly used in sleep studies are the Pittsburgh Sleep Quality Index (PSQI), and sleep-wake diaries. PSQI has been validated in good sleepers $(n=52)$, depressive poor sleepers $(n=54)$, and sleep-disorder patients $(n=62)$. The PSQI reveals a high internal homogeneity and high test-retest reliability. The scale was determined to have a high sensitivity and specificity to classify sleep disorders, $89.6 \%$ and $86.5 \%$ 
respectively (Buysse, Reynolds III, Monk, Berman, \& Kupfer, 1988). Implications for use within the study were to classify sleepers and determine the effect of sleeping behavior.

Sleep logs provide another subjective measure to compare to sleep quality in studies. Carskason and research partners created the school sleep habits survey. The scale was validated in 3,120 high school students at four public high schools. The scale determined when the adequate value of sleep in adolescents was close to 8 hours and 15 minutes (Wolfson et al., 1998). Participants who slept at least eight hours reported fewer problems with sleep-wake and lower depressive moods. The scale was further validated against wristwatch actigraphy. Sleep scale was significantly correlated with sleep dairy and actigraphy variables, with sleep times within five minutes of each other (Wolfson, Carskadon, Acebo, Seifer, Fallone, Labyak, \& Martin, 2003). A sleep log is added to many sleep studies to determine individuals' self-reported sleep times. Specifically, the sleep-wake journal created by Carskadon has been validated on male $(n=106)$ and female $(n=196)$ high school students in comparison with sleep diaries and actigraphy (Wolfson et al., 2003). This sleep-wake journal reveals high test-retest reliability in adolescent participants. Carskadon cites ease of use from the close-ended questions and established codes for each question as popular reasons for use in experimental studies (2003).

Objective measures of sleep include polysomnography and actigraphy. Polysomnography is the most common sleep test; however, it is costly and requires expert knowledge to process the data. These tests are administered in a sleep lab. The subject is connected to an EEG, electrocardiogram (EKG), and electromyography (EMG) during a full night's rest. The EEG, EKG, and EMG measure subject's brain waves, heart 
signals, and muscle movement, respectively. Actigraphy is more common due to a small wrist or hip worn device that monitors daily activity. It is considered the most common measure in community-based research (Kinder, Lee, Thompson, Hicks, Topp, \& Madsen, 2012). Wrist worn activity watches are exceeding popular in present day due to the ease of use. Fitbit watches continue to gain support in the scientific community due to their high inter-relatability between the watches and actigraphy measures in health adults (Montgomery- Downs, Isana, \& Bond, 2012). However, the cost makes wristwatch actigraphy impractical due to lack of funding. Accelerometers have remained present in physical activity research and have established a high reliability in both aerobic exercise and weight lifting exercises (Sato, Smith, \& Sands, 2009). A study conducted on professional Australian football players during practice and game play determined running stride from accelerometers was highly correlated with speed obtained from a global positioning satellite. Furthermore, the study reported accelerometer can determine the intensity of movement during a sprint (Neville, Wixted, Rowlands, \& James, 2010).

\section{Literature Review Conclusion}

Given these points it is generally accepted that sleep plays a major role in our daily life. The theory behind sleep is still in the making but research supports the claim that sleep is needed for muscle repair, hormone regulation, learning, and memory. On average individuals regardless of age or gender should sleep at least eight hours per night to combat depressive states and improve resistance to metabolic disease (Youngstedt et al, 2006; Crispim et al,2007). Exercise and sleep take this further by combining two modalities to increase health and provide stress release. When performing exercise it is 
important to determine intensity, duration, and modality. Chronic effects of exercise are reported in this paper to improve sleep measures and aid a healthy life. 


\section{METHOD}

As previously mentioned, research involving sleep patterns and their effects on sport performance are limited. Researchers have found sleep plays a role in sport performance by measuring POMS scores, reaction time, as well as sport performance test, such as free throw shots (Scott et al, 2004 and Mah et al, 2011). Participants who are deprived of sleep report lower POMS scores and slower reaction times in comparison to non-sleep deprived participants in the same experiment (Scott et al, 2004). Further, participants in sleep extension have improved sports performance scores, as measured by the 3-point shot and free throws in basketball athletes (Mah et al, 2011). Based on the literature, this study has chosen to use the PSQI and SWJ by Carksadon to examine sleep patterns in adolescent athletes. The study also uses $40 \mathrm{~m}$ sprints and the beep test to act as sport performance tests to determine if a correlation is present between sleep patterns and sport performance scores.

\section{Participants}

As this study was conducted on adolescent athletes and sport performance, our subject selection was comprised of female athletes on a high school field hockey team at a local high school. This sample was selected, as field hockey is the third largest sport in the world, with 128 member associations within five confederations recognized by the 
International Hockey Federation. The USA Field Hockey governing body includes over 25,000 members (FIH, 2015). IRB approval was granted from the University, approval \#15.0415. Every subject was provided with an informed assent form and every subject's parent was provided with an informed permission form. The informed assent form and informed consent form explained participant' responsibilities and risks by participating in the study. After the investigator explanation of the study and all participants questions were answered, every subject signed the form to agree to be part of the study. All consent and assent forms were obtained prior to the study. The forms were kept in a locked file cabinet, and a copy of each form was given back to each participant. There was a familiarization period of one week within all participants completed the beep test procedures, six 40m sprints, and explanation of the PSQI and SWJ.

To be eligible for the study participants had to be a member of one of the field hockey teams (varsity, junior varsity, freshmen) as well as participate in $90 \%$ of all training sessions and all testing sessions. Participants were excluded if they did not meet attendance requirements or suffered an injury, which affected study parameters. Participants with injuries were allowed to participate, but their results were not included in the statistical analysis.

Demographic characteristics were obtained from each subject through a self-report. Height was taken utilizing a stadiometer inside the field hockey facility without shoes. Participants stood facing forward with their back straight against the stadiometer. Hands were placed down to their sides and head is looking straight ahead. Participants were instructed to refrain from slouching and place both feet flat on the ground. Weight was taken on a Brecknell HS-200M Physician Scale within the field hockey facility on hard 
floor to control for any absorption that may take place on short flooring. Calibration of the scale took place before every testing day. A known mass of $4.5 \mathrm{~kg}(\sim 10 \mathrm{lbs})$ was placed on the scale to determine accuracy. Body mass index (BMI) was calculated for each subject.

\section{Objective Testing Validation}

Forty-one EKHO Six MVPA tri-axis accelerometers were used for data collection. Four accelerometers were chosen for validation before data collection. Experimenters chose every tenth accelerometer from the data set. The decision to limit data collection to EKHO Six MVPA tri-axis accelerometers was due to the ease of calculating step count, the clam shell case to prevent screen damage and an alligator clip to fasten accelerometer to hip. The step count is the only measure taken from the tri-axis accelerometers. The step count normative data used in this study is provided by Tudor-Locke and Bassett (2004). EKHO accelerometers have not been validated in research and therefore the step count was validated using the 30 -second shake test, 20 step walking test and a treadmillwalking test before beginning data collection on particpants. These tests have been used for validation measures in research accelerometers (Tudor-Locke, Sisson, Lee, Craig, Plotnikoff \& Bauman, 2006). If reliability and accuracy of accelerometers reveals a percent error of $5 \%$ or less, step count is added to the results section. Researchers selected five accelerometers from the accelerometer box to determine percent error.

30 second shake test $\mathrm{A}$ subject holds the accelerometer in their dominant hand. A stopwatch timer is used to determine thirty seconds. A video camera observes total number of shakes. Subject zeros the step count before holding the reset button for three 
seconds collects data. Subject begins shaking the accelerometer for the full thirty seconds. Video recording is reviewed to determine the amount of shakes administered in the thirty-second session by the researcher. Once calculated the accelerometer reading of step count is compared to 0 to determine accuracy. Step count from the shakes should read 0 , as subject is not moving during testing. Any number over 1-step count on the accelerometer is labeled as inaccurate.

20 Step test Accelerometer is attached to the subject at the waist with the secure clip on the back of the device. Accelerometer should be in line with the midline of the thigh and over the dominant foot. Step count should be zeroed before beginning test. Subject is instructed to take twenty steps at a normal pace. Total number of steps recorded should be divided by the twenty steps; this equation determines step error. An error of 1 step (5\% error) is considered unacceptable for research purposes (Vincent \& Sidman, 2003).

Treadmill 1 minute Accelerometer is attached to the subject at the waist, along the midline of the thigh and over the dominant foot. Once accelerometer is zeroed the subject should step onto a Wood way treadmill. Subject's lower body is recorded to determine actual total step counts in one minute of treadmill walking at an $80 \mathrm{~m}$ per min $(3 \mathrm{mph})$. Three miles per hour was chosen based on average walking speed and optimal speed for step count collection (Bassett Jr, Ainsworth, Leggett, Mathien, Main, Hunter and Duncan, 1996). Subject should start treadmill at $80 \mathrm{mpm}$ stride and be instructed to maintain stride for one minute. Accelerometer error (step count detected - actual steps /actual steps x 100) is used to determine accuracy and reliability.

All accelerometer testing was performed in the Louisville Exercise Physiology Lab. 


\section{Setting}

All physiological testing occurred on a local field hockey field. Demographic characteristics were obtained at the school's field hockey facility. During all testing sessions air quality, temperature, and humidity were closely monitored per Kentucky High School Athletic Association standards using a digital psychrometer. Demographics and SRPD questionnaires were filled out online using the Qualtrics platform (Provo, UT). SWJ and PSQI was completed at the participants' home and returned to the researchers after the four-day period.

\section{Testing}

Pubertal tanner stage reporting is common in studies using adolescents as their research population. This is due to the diversity in hormones during this period in children's lives. Tanner staging is typically performed in hospital settings. The doctor observes the presence of hair growth and genital development along with secondary sex characteristics in males and females. In research designs self-reporting of staging are becoming more prevalent as this measure is less invasive. The self-administered rating scale for pubertal development reports a high internal consistency between self-report, parent-reported, and interviews based on pubertal scale (Carskadon, \& Acebo, 1993).

Physiological testing chosen is based on field-based maximal effort testing in aerobic capacity and anaerobic capacity. Aerobic capacity and anaerobic capacity are both vital components of fitness in a female high school field hockey athlete, as a typical field hockey game can last up to 2 hours with sprints varying between $10 \mathrm{~m}$ to $40 \mathrm{~m}$ per ball carry. A typical game consists of $6798 \pm 2009$ m total distance covered with a $34 \pm 12$ 
sprints on average per player at 3.3 seconds each (Lythe \& Kilding, 2011). The physiological tests chosen are based on the testing battery conducted on collegiate athletes (Keogh, Weber, \& Dalton, 2003). Aerobic capacity is tested through the multistage fitness test shuttle run, also known as the beep test. The beep test is considered valid for estimating VO2max in a sport-specific environment that mimics field play (Reilly, 2001 and Nieuwenhuise, 2010). Anaerobic capacity is determined based on the repeated sprint ability test, which includes six $40 \mathrm{~m}$ sprints at maximal effort, which have been shown to be specific for field hockey sport demands (Reilly, 2001).

The PSQI, SWJ, demographics and SRPD were given to each participant on the first day of testing. Demographics and self-administered rating scale were taken online using Qualtrics (Provo, UT). The SRPD was sent out through email to each subject. Participants were required to take all surveys alone and in private as the questions on the pubertal development survey may create uncomfortable feelings and participants may be embarrassed in front of their teammates. The PSQI and SWJ were given out to each subject beginning the first day of testing. The PSQI was used to determine if any athletes suffered from a sleep disorder, as well as obtaining sleep variables. Sleep variables from the PSQI used for data analysis included: sleep latency, overall sleep quality, and duration of sleep. The two measures used from the sleep-wake journal for analysis included: onset of sleep time and concentration. The SWJ was given to the participants on the first day of testing to complete for the next seven days (7 nights, 7 days). SWJs were taken home with each subject and completed in the morning of testing and before bed on each of the testing days. 
The beep test and six $40 \mathrm{~m}$ sprints were completed in the first week of pre-season training with 48 hours between each test to serve as a familiarization. The beep test consists of a running distance of $20 \mathrm{~m}$. A pre-recording of beeps that becomes progressively faster is played. The athletes must complete the shuttle run until they reach exhaustion. The repeated sprint ability test includes six $40 \mathrm{~m}$ sprints. Cones are placed at the starting line at $0 \mathrm{~m}$, end of acceleration phase at $10 \mathrm{~m}$, and end of sprint at $40 \mathrm{~m}$. The acceleration speed from $0 \mathrm{~m}$ to $10 \mathrm{~m}$ was taken via stopwatch by a researcher, as the athlete runs past the $10 \mathrm{~m}$ mark. The top-end speed was determined as the time in seconds the athlete sprinted from $0 \mathrm{~m}$ to $40 \mathrm{~m}$. One week after the familiarization trails the beep test and six $40 \mathrm{~m}$ sprints were completed.

\section{Training protocol}

Pre-season training protocol was as prescribed by the teams' coaches. It included endurance training, interval training, sprint training, and skill training. Preseason training was five days a week for two hours and two mornings for 1.5 hours.

\section{Research design}

A correlational design was used in which a convenience sample of female high school field hockey players were used. The study involved only one test group and therefore comparisons cannot be made between groups. Performance tests and sleep variables were only taken once during the study. Therefore, researchers could only compare between performance tests and sleep variables. Since there was only one test block any comparisons made would be correlational and not causational.

\section{Table 1}


Intervention Description

\begin{tabular}{|c|c|}
\hline Testing Dates & Procedures \\
\hline Week 1 & $\begin{array}{l}\text { Familiarization of beep test } \\
\text { Familiarization of } 10 \mathrm{~m} / 40 \mathrm{~m} \text { sprint }\end{array}$ \\
\hline Week 2 & $\begin{array}{l}\text { Beep test } \\
\text { 10m/40m sprint } \\
\text { Demographics survey through Qualtrics } \\
\text { SRPD (Qualtrics) } \\
\text { Hand out PSQI } \\
\text { Hand out SWJ }\end{array}$ \\
\hline Week 3 & $\begin{array}{l}\text { Receive all questionnaires (PSQI, SWJ, } \\
\text { demographics and SRPD) }\end{array}$ \\
\hline Week 4 & Data entry into SPSS statistics \\
\hline Week 5 & Data analysis through SPSS statistics \\
\hline Week 6 & Result Documentation \\
\hline
\end{tabular}

\section{Statistical analysis}


Objective sleep/wake times were measured on a ratio scale. Time in minutes is the measurement for total sleep hours. A parametric Pearson's $r$ correlation test was performed $(p<0.05)$. Self-rating of pubertal development as well as subjective sleep measures from the PSQI and sleep-wake diary was determined using a nonparametric Spearman's Rho $(p<0.05)$. Spearman's Rho test was used on the subjective measures because the data taken from the dependent measure is ordinal. Pedometer activity, along with subjective sleep measures from PSQI and SWJ, were compared to determine if correlations are present.

From the PSQI the three measures chosen for analysis were: sleep latency, overall sleep quality, and duration of sleep. The onset of sleep time and concentration were two measures used from the sleep-wake journal for analysis.

The data was analyzed by a statistical software package (SPSS Version 21.0, IBM SPSS Statistics Inc., Chicago, IL). Statistical significance was declared when $p<0.05$ unless otherwise noted.

\section{Sample size calculation}

In order to determine the sample size $\mathrm{G}$ power $\left(\mathrm{G}^{*}\right.$ Power Version 3.1.7, Universität Kiel, Germany) was used. An independent $t$-test was chosen for comparison between sleeping well and non-sleeping well groups. Effect size chosen was a medium effect (0.25). Alpha level, type 1 error, was selected at 0.05. Power (1-B error probability) was kept at 0.80 . There is one group and nine separate measures that were examined. The nine separate measures are: PSQI, onset of sleep, SL, total sleep time, QOS, concentration level, beep test scores, acceleration speed, and top-end speed. The correlation among 
repeated measures was kept at 0.5 . The non-sphericity correction e was 0.5 . The sample size determined was 19 participants $(d f=18)$. To account for subject mortality the total subject count was kept at 32 participants.

\section{Data management and storage}

Data was recorded manually on formatted collection sheets for each survey. Sleepwake diary collection sheets are formatted according to Mary Carksadon (Wolfson \& Carskadon, 2003). All collection sheets are collected by the researchers and filed in a locked cabinet at the office of the faculty adviser. The office is to be locked at all times when the faculty member is not present and access was only granted to the given researchers and faculty adviser. An electric file backup is saved on password-protected computers at the faculty adviser's office. 


\section{RESULTS}

Thirty-two participants were recruited for participation during the study. During the study, participants were required to complete a PSQI, seven days of SWJs, demographics survey and SRPD. Familiarization sessions were performed for both performance tests: beep test and six 10m/40m sprints. After one week, participants then completed both sport performance tests for data collection. Participants were instructed to submit complete demographics survey and SRPD on Qualtrics (Provo, UT). Participants completed hard copies of the PSQI and SWJs to turn into the investigators during week 3 of the study (see timeline in methods).

\section{Accelerometer Validation}

Accelerometers were not passed to the students for step count, based on failure of accelerometers to collect accurate step count. From the four chosen accelerometers for validation only one had a $67 \%$ accuracy rate, two had a $33 \%$ accuracy rate, and one had a $0 \%$ accuracy rate.

\section{Table 2}

Accelerometer validation measurements. 


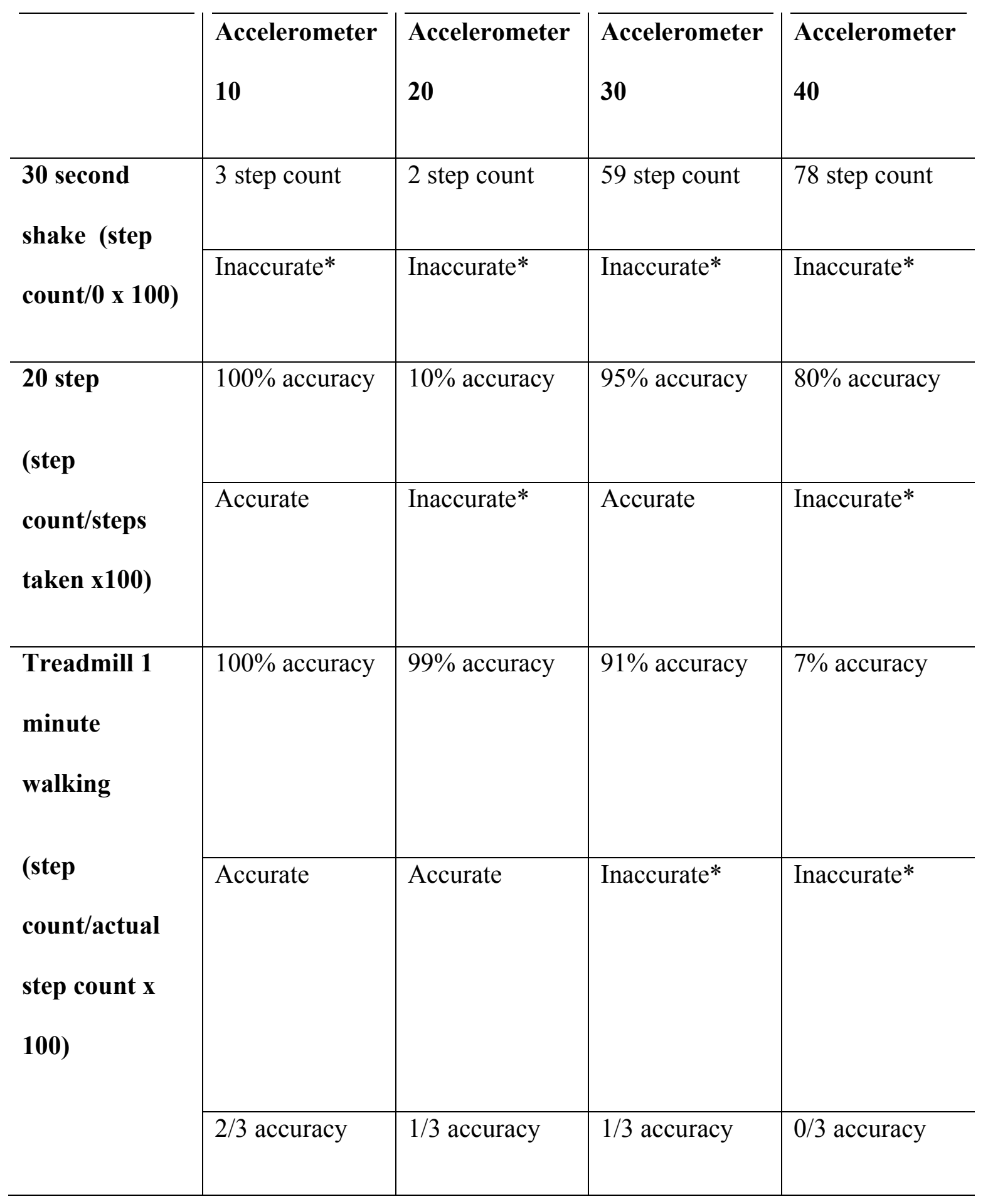

\section{Questionnaires}

Of the 35 participants, 27 completed the PSQI and SRPD. Only 15 participants turned in at least 4 days of SWJs. Due to the low return rate of SWJs, the investigators chose to 
include only 4 days of SWJs instead of 7 days of SWJs. Reasons for failure to complete surveys were subject withdrawal due to school transfer $(n=1)$ and failure to return SWJS $(n=19)$. Only a complete set including PSQI, SRPD, and four days of SWJs were used for statistical analysis. All scales and questionnaires missing information were unable to be processed and therefore excluded from statistical analysis. All data was normally distributed. There were no differences between any of the participant characteristics (Table 3).

Table 3

Participant characteristics

\begin{tabular}{cccc}
\hline & Mean (SD) & Minimum & Maximum \\
\hline Age (yrs) & $15.47(1.01)$ & 14.46 & 16.48 \\
Height (cm) & $161.45(7.15)$ & 154.30 & 168.60 \\
Weight (kg) & $59.04(10.02)$ & 49.02 & 69.06 \\
Body Mass Index \\
$\left(\mathrm{kg} / \mathrm{m}^{2}\right)$
\end{tabular}

Participants' identified races were white/Caucasian with no Hispanic origin $(n=13)$, white/Caucasian with Hispanic origin $(n=1)$, and African American with no Hispanic origin $(n=1)$. Of the 15 participants, only 6 were employed part-time, with an average workload of 15 hours. 


\section{Table 4}

PSQI, SWJ, demographics and SRPD

\begin{tabular}{cccc}
\hline & Mean (SD) & Minimum & Maximum \\
\hline PSQI & $3.07(1.49)$ & 1.58 & 4.56 \\
Sleep Latency (min) & $20.51(18.10)$ & 2.41 & 38.61 \\
Quality of Sleep & $2.78(0.80)$ & 1.98 & 3.58 \\
Total Sleep Time & $529.90(53.11)$ & 476.79 & 583.01 \\
$\quad \begin{array}{l}\text { (min) } \\
\text { Onset of Sleep }\end{array}$ & $3.64(0.79)$ & 2.85 & 4.43 \\
Concentration & $3.72(0.59)$ & 3.13 & 4.31 \\
Pubertal Stage & $3.49(0.48)$ & 3.01 & 3.97 \\
\hline
\end{tabular}

Mean (SD)

PSQI revealed no participants suffered from sleep disorders. All PSQI and SWJ measures were normally distributed. The self-reported pubertal stage revealed subjects $(n=13)$ were classified as mid-pubescent, with participants $(n=2)$ classified as early pubescent. There were no PSQI or SWJ differences between mid and early pubescent level.

\section{Sports Performance}

\section{Table 5}

Performance testing: beep test and $10 \mathrm{~m} / 40 \mathrm{~m}$ average sprint time (secs)

\begin{tabular}{cccc}
\hline & Mean (SD) & Minimum & Maximum \\
\hline Beep Test & $6.44(1.05)$ & 5.39 & 7.49 \\
$10 \mathrm{~m}$ sprint (sec) & $2.58(0.14)$ & 2.44 & 2.72 \\
\hline
\end{tabular}


Participants' beep test scores and 10/40m sprint were normally distributed. There were no differences in test scores between mid and early pubescent level.

\section{Correlations between sleep and sport Performance}

\section{Table 6}

Correlations across variables.

$n=15$. Bold $=$ Pearson Correlation. Italics $=$ Significance 2 tailed. $* *$. Correlation is significant at the 0.01 level (2-tailed). *. Correlation is significant at the 0.05 level (2tailed).

\begin{tabular}{|c|c|c|c|c|c|c|c|}
\hline & $\begin{array}{l}\text { Beep } \\
\text { Test }\end{array}$ & $\begin{array}{l}\text { 10m avg } \\
\text { sprint } \\
\text { (sec) }\end{array}$ & $\begin{array}{l}40 m \\
\text { avg } \\
\text { sprint } \\
\text { (sec) }\end{array}$ & 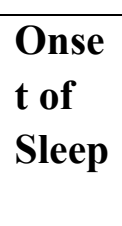 & $\begin{array}{l}\text { SL } \\
(\min )\end{array}$ & $\begin{array}{l}\text { TST } \\
\text { (min) }\end{array}$ & $\begin{array}{l}\text { Concentr } \\
\text { ation }\end{array}$ \\
\hline \multirow{2}{*}{$\begin{array}{l}\text { 10m average } \\
\text { sprint time } \\
\text { (seconds) }\end{array}$} & -0.028 & & & $\overline{-}-128$ & 0.214 & -0.045 & -0.014 \\
\hline & 0.92 & & & 0.648 & 0.443 & 0.874 & 0961 \\
\hline \multirow{2}{*}{$\begin{array}{l}\text { 40m average } \\
\text { sprint time } \\
\text { (seconds) }\end{array}$} & -0.265 & $0.896 * *$ & & & 0.178 & -0.067 & -0.003 \\
\hline & 0.339 & 0 & & & 0.526 & 0.757 & 0.991 \\
\hline \multirow[t]{2}{*}{ OS } & $-0 / 04$ & -0.128 & -0.168 & & & & -0.332 \\
\hline & 0.896 & 0.648 & 0.549 & & & & 0.227 \\
\hline \multirow{2}{*}{$\begin{array}{l}\text { Sleep Latency } \\
\text { (min) }\end{array}$} & -0.155 & 0.214 & 0.178 & -0.06 & & & 0.043 \\
\hline & 0.58 & 0.443 & 0.526 & 0.8 & & & 0.878 \\
\hline
\end{tabular}




\begin{tabular}{|c|c|c|c|c|c|c|}
\hline \multirow[t]{2}{*}{$\begin{array}{l}\text { Total Sleep } \\
\text { Time (min) }\end{array}$} & 0.106 & -0.045 & -0.087 & $\begin{array}{l}- \\
0.596 \\
*\end{array}$ & -0.275 & \\
\hline & 0.708 & 0.874 & 0.757 & 0.019 & 0.321 & \\
\hline \multirow[t]{2}{*}{ Concentration } & 0.076 & -0.014 & -0.003 & $\begin{array}{l}- \\
0.332\end{array}$ & 0.043 & 0.194 \\
\hline & 0.787 & 0.951 & 0.991 & 0.227 & 0.878 & 0.489 \\
\hline
\end{tabular}

There were no correlations found between sleep measures and performance tests. A positive strong correlation exists between $40 \mathrm{~m}$ average sprint time and $10 \mathrm{~m}$ average sprint time (0.896). A negative correlation exists between onset of sleep and total sleep time (-0.596). Both hypotheses were not supported by the results. 


\section{DISCUSSION}

The purpose of this study was to determine if a correlation was present between sleep measures and performance test in high school female field hockey athletes. We wished to assess whether sleep variables would determine high and low performers based on physiological testing. We hypothesized athletes who sleep more than 8 hours each night would have a higher beep test score and faster $40 \mathrm{~m} / 10 \mathrm{~m}$ sprint times. There was no correlation between sleep variables and physiological testing as we hypothesized.

There are six factors that we need to look at when using a correlation coefficient. Those are: amount of variability in the data set, distribution differences, lack of linearity, outliers, sample characteristics, and measurement error. If we look at standard deviation in sleep measures (onset of sleep, concentration, and quality of sleep), as well as sprint times and pubertal staging, we see a low variance between the participants. Due to this low variance the correlation coefficient would be lowered. The shapes of all measurements were normally distributed and no outliers were present. The data points were nonlinear and therefore the correlation coefficient will be low regardless. To the knowledge of the researcher, there are no unique characteristics of the sample that would affect the correlation coefficient. Finally, the measurement error in this sample could lend to error in the correlation coefficient. The measurement error decreases the reliability of the variable measures. The decrease reliability comes from various factors, such as administrative factors, environmental factors, fatigue, anxiety and guessing. The 
environment of the beep test and sprint data was done outside on a humid, summer day. This could lead to a decrease in performance, as participants in humid environments experience a faster sweat rate loss compared to those in a non-humid environment (Murphy, 1984). Participants were able to ask the researchers any questions that had while filling out the questionnaires. However, some participants may have guessed on their questionnaires, especially on those related to sleep times. The sleep-wake journal was as close-ended as possible when asking for the total sleep time and the onset of sleep time, however participants may have trouble remembering these times and recording them the following morning. Performance tests were completed with a stopwatch in place of a time gate system due to cost. The administrator of the test could be on average 0.3 seconds difference when compared to an electrical time gate (Ebben, Petushek \& Clewein, 2009). All of these instances could result in a decrease of reliability and further result in a large measurement error.

\section{Performance Implications}

We expected to capture a brief picture of sleep variables along with physiological testing; however, due to the short data collection period we may not have captured a total picture of each participant's sleep patterns. A data collection period lasting at least seven days encompassing a Monday to Sunday rotation would accurately capture the weekly sleep patterns of each subject. However, obtaining such measures require dedication and effort on the part of the participant and a significantly higher follow through compared to the 4 days of data collection. Moving forward with this line of research it would be important to pick a higher motivated sample, as it would be more likely that their 7-day sleep-wake journals would be complete. 


\section{Study Limitations}

One of the largest limitations of this study was the small sample size chosen. Athletes were on summer break. A large percentage of our participants failed to submit their surveys, as they reportedly forgot and were unable to complete the study in the 4-day collection period. The low sample size decreased the power of the study. Another limitation of the study was a lack of an objective measure for sleep patterns, as polysomnography is was too costly of a procedure to be conducted on the athletes. The accelerometers used for the participants were unable to record any data usable for the study. Participants reported forgetting to reset their accelerometer daily to capture sleep measures. Participants also reported not wanting to wear the accelerometer at night, as it disturbed those who slept on their side or bellies.

Another possible limitation of this study includes the testing time being conducted during the summer in pre-season training, when adolescents have been known to increase sleep pattern variability. By capturing a longer data collection period, as discussed above, the data may display a more accurate picture of athletes' sleep patterns.

\section{Conclusion}

In conclusion, this study demonstrated these important findings:

1. Sleep patterns, (such as onset of sleep, sleep latency, total sleep time, quality of sleep and concentration level), were not significantly correlated with beep test scores, acceleration speed, or top-end speed in female high school field hockey athletes. This study aimed to fill the gap in research on a sport-specific field performance testing on sleep measures in adolescent athletes. The results are the first of its kind on adolescent athletes, and further is the only study conducted on 
adolescent female field hockey players. Compared to past sport-specific research, it is surprising that sleep patterns and performance testing possessed no correlations. The past research all revealed associations between sleep and sportspecific parameters. Finally, when reviewing reasoning for any missed correlation, it was suggested that measurement error could of occurred in both guessing in questionnaires on sleep times and administrator error with the stopwatch on the sprint times.

2. A longer sleep patterns data collection should be included in analysis of further studies to accurately portray athletes' sleep patterns. A 7-day sleep-wake journal collection period was the original recommendation of this study. However, the researchers only received 4 days of sleep-wake journals. Instead of excluding the data from the results, the researchers hoped to still draw comparisons. Moving forward, it would be interesting for further research to include an objective measure of sleep patterns. As previously mentioned, subjective measures could be skewed based on participants' guessing sleep times. Wrist-worn activity watches, such as Fitbit watches, have gained popularity in current research and show high inter-reliability between actigraphy measures. These wrist-worn activity watches provide similar sleep times when compared to the gold standard of sleep measurement, polysomnography.

3. With regard to sleep measures, athletes' whose onset of sleep is early reported a higher total sleep time, compared to athletes' with late onset of sleep times. There may be a delayed waking time in athletes' bedding early. This finding is particularly interesting as new research is being conducted currently on this trend. 
Current research suggest participants who go to go to sleep early are more likely to have a lower intelligence score than those who go to sleep later (Roberts \& Kyllonen, 1999). There is research to suggest melatonin levels are higher and dopamine levels are lower in those who go to sleep early compared with those who go to sleep later (Natale, Adan \& Chotai, 2002). The current study contributes to the tie between early sleepers and increased total sleep time.

\section{Future Research Directions}

With regards to sleep patterns, it is interesting to note that our study discovered a correlation between early onset of sleep and longer total sleep times. Future research could add the Profile of Mood States (POMS) test to determine if the increases sleep times was associated with depression and dejection scores. Since prior research focused on the dopamine levels and sleep patterns, it would be interesting to take that a step further. A research question determining any association between depression and dejection scores from the POMS, early onset of sleep, total sleep times, and dopamine levels could fill the research gap.

Further, both physiological testing and sleep patterns have been proven in research to impact game play the day before and the day of. Adding the Sport Motivation Scale (SMS) would determine total motivation during sport play. The results from the motivation scale can be compared to sleep patterns. It is the hypothesized that the athletes with a higher total sleep time would have a higher sport motivation score.

Finally, the current study could be repeated with the addition of an accelerometer. The accelerometer provides the objective sleep patterns. The objective sleep patterns would 
decrease the measurement error from the self-report of sleep patterns. A decrease in measurement error would increase the reliability of variable measures.

In conclusion, this study created more questions than it answered. Answering these questions can further the research gap, as well as discovering total sleep times that should be recommended for athletes to improve sport performance. 


\section{REFERENCES}

Atkinson G \& Reilly T. (1996). Circadian variation in sports performance. Sports Med. 21(4), 292-312.

Bassett DR Jr, Ainsworth BE, Leggett SR, Mathien CA, Main JA, Hunter DC and Duncan GE. (1996). Accuracy of five electronic pedometers for measuring distance walked. Med Sci Sports Exerc. 28(8), 1071-1077.

Baxter C \& Reilly T. (1983). Influence of time of day on all-out swimming. Br J Sports Med. 17(1): 122-127.

Besedovsky L. Lange T \& Born J. (2012). Sleep and Immune Function. Euro J Physiol. 463(1): 121-137.

Buysse DJ, Reynolds III CF, Monk TH, Berman SR \& Kupfer DJ. (1988). The Pittsburgh Sleep Quality Index: A New Instrument for Psychiatric Practice and Research. Psych Res. 28(1), 193-213.

Carskadon MA \& Acebo C. (1993). A self-administered rating scale for pubertal development. J Adolescent Res. 14(1), 190-195.

Crispim CA, Zakam I, Dattilo M, Padilha HG, Edwards B, Waterhouse J, Tufik S and de Mello MT. (2007). The influence of sleep and sleep loss upon food intake and metabolism. Nutr Res Rev. 20(2), 195-212.

Crowley SJ, Acebo C, Carskadon MA. (2007) Sleep, circadian rhythms, and delayed phase in adolescence. Sleep Med.8(6):602-612.

Daros LB, Osiecki R, Dourado AC, Stanganelli LCR, Fornaziero AM and Osiecki ACV. (2012). Maximum Aerobic Power Test for Soccer Players. JEP. 15(2): 80-89.

Duxbury J. (1994). Understanding the nature of sleep. Nurs Stand.9(9), 25-28.

Ebben WP, Petushek EJ \& Clewein R. (2009). A comparision of manural and electrical Timing during 20 and 40 yard sprints. JEP Online. 12(5), 34-39.

Freeman ME, Kanyieska B, Learny A \& Nagy G. (2000). Prolactin: structure, function, and regulation of secretion. Physiol Rev. 80(4): 1523-1631. 
Fullagar HHK, Skorski S, Duffiled R, Hammes D, Couts AJ \& Meyer T. (2015). Sleep and athletic performance: the effects of sleep loss on exercise performance and physiological and cognitive responses to exercise. J Sports Med.45(2), 161-186.

Gumustekin K, Steven B, Karabulut N, Aktas O, Gurson N, Aslan S, Keles M, Varoglu E and Dane S. (2004). Effects of sleep deprivation, nicotine, and selenium on wound healing in rats. Int J Neurosci. 114(11), 1433-1442.

Halson SL. (2008). Nutrition, sleep, and recovery. Euro J Sport Sci. 8(2), 119-126.

Haslon SL. (2013). Sleep and the elite athlete and nutritional interventions to enhance sleep. Sports Med.44(1), 13-23.

Institute of Medicine (US) Committee on Sleep Medicine and Research; Colten HR, Altevogt BM, editors. (2006). Sleep Disorders and Sleep Deprivation: An Unmet Public Health Problem. Sleep Physiology. Washington (DC), US: National Academies Press.

International Hockey Federation [FIH]. (2015). History of Hockey. Retrieved from http://www.fih.ch/en/fih/history.

Keogh JW, Weber CL, \& Dalton CT. (2003). Evaluation of anthropometric, physiological, and skill-related tests for talent identification in female field hockey. Can J Appl Physiol. 28(1), 397-409.

Kinder JR, Lee KA, Thompson H, Hicks K, Topp K and Madison KA. (2012). Validation of hip-worn accelerometer in measuring sleep time in children. J Pediatr Nurs. 27(1), 127-133.

Kline CE, Durstine JL, Davis JM, Moore TA, Devlin TM, Zielinski MR, and Youngstedt SD. (2007). Circardian variation in swim performance. J Appl Physiol. 102(1):641-649.

Le Bon O, Stander L, Hoffmann G, Dramaix M, San Sebastian I, Murphy JR, Kentos M, Pelc I and Linkowski P. (2001). The first-night effect may last more than one night. J Psychiatr Res. 35(3), 165-173.

Lythe J \& Kilding AE. (2011). Physical Demands and Physiological Responses During Elite Field Hockey. Int J Sports Med.32(1):523-528.

Mah CD, Mah KE, Kezirian EJ \& Dement WC. (2011). The effects of sleep extension on the athletic performance of collegiate basketball players. Sleep. 34(7), 943950. 
Marklund P, Mattsson CM, Wahlin-Larsson B, Ponsot L, Lindvall B, Lindvall L, Ekblon B and Radi F. (2013). Excessive inflammatory cell infiltration in human skeletal muscle in response to an ultraendurance exercise bout in experience athletes. J Appl Sci. 114(1), 66-72.

Miki K \& Yoshimoto M. (2012). Sympathetic nerve activity during sleep, exercise, and mental stress. Auton Neurosci. 174(2013), 15-20.

Ming X, Koransky R, Kand V, Buchman S, Sarris CE and Wagner CE. (2011). Sleep insufficiency, sleep health problems and performance in high school students. Clin Med Insights Circ Respir Pulm Med. 5(1), 71-79.

Murphy RJ. (1984). Heat Illness in the athlete. Am J Sports Med. 12(1), 258-261.

Myllymäki T., Kyröläinen H., Savolainen K., Hokka L., Jakonen R., Juuti T., Martinmäki K., Kaartinen J., Kinnunen M.-L., Rusko H. (2011). Effects of vigorous late-night exercise on sleep quality and cardiac autonomic activity. J. Sleep Res. 20(1), 146 153.

Natale V, Adan A \& Chotal J. (2002). Further results on the association between morningness-eveningness preference and the season of birth in human adults. Neuropsychobiology. 46(4), 209-214.

Neville J, Wixted A, Rowlands D \& James D. (2010). Accelerometers: An underutilized resource in sports monitoring. IEEE. Paper presented at 2010 Sixth International Conference on Intelligent Sensors, Sensor Networks and Information Processing, Australia (287-290).

Nieuwenhuis CF, Spamer EJ and van Rossum JHA. (2010). Predicition Function for Indeitifying Talent in 14- to 15- Year-old Female Field Hockey Players. High Abil Stud. 13(1), 21-33.

Pope DC \& Simon R. (2005). Help for Stressed Students. The Adolescent Learner. 62(7), 1-6.

Reilly T. (2001). Assessment of sports performance with particular reference to filed games. Eur J Sport Sci. 1(3), 1-12.

Reilly T, Waterhouse J and Atkinson G. (1997). Aging, rhythms of physical performance, and adjustment to changes in the sleep-activity cycle. Occup Environ Med. 54(11), 812-816.

Roberts RD \& Kyllonen PC. (1999). Morningness-eveningness and intelligence: early to 
Bed, early to rise will likely make you anything but wise! Pers Individ Dif. 27(6), 1123-1133.

Sato K, Smith SL \& Sands WA. (2009). Validation of an accelerometer for measuring sports performance. J Strength Cond Res. 23(1), 341-347.

Scott JPR, McNaughton LR \& Polman RCJ. (2004). Effects of sleep deprivation and exercise on cognitive, motor performance and mood. Physiol Behav. 87(2006), 396-408.

Shapiro CM. (1981). Sleep and the athlete. Br J Sport Med. 15(1), 51-55.

Taylor, S.R. (2001). The influence of exercise on sleep quality. Int Sports Med. 2(3), 110.

Thun E, Bjorvtan B, Flor E, Harris A and Pallesen S. (2015). Sleep. Circadian rhythms, and athletic performance. Sleep Med Rev. 23(1), 1-9.

Tudor-Locke C \& Bassett DR Jr. (2004). How many steps/day are enough?

Preliminary pedometer indices for public health. Sports Med.34(1), 1-8.

Tudor-Locke C, Sisson SB, Lee SM, Craig CL, Plotnikoff RC and Bauman A. (2006). Evaluation of quality of commercial pedometers. Can J Public Health. 97(1), S10-5, S10-6.

Urade Y \& Hayaishi O. (2011). Postaglandin D2 and sleep/wake regulation. Sleep Med Rev. 15(6): 411-418.

Vincent SD \& Sidman CL. Determining measurement error in digital pedometers. Meas Phys Educ Exerc Sci.7(1), 19-24.

Wolfson AR, Carskadon MA, Acebo C, Seifer R, Fallone GG, Labyak SE and Marting JL. (2003). Evidence for the validity of a sleep habits survey for adolescents. Sleep. 15(26): 213-216.

Wolfson AR \& Carskadon MA. (1998). Sleep schedules and daytime functioning in adolescents. Child Development. 69(4), 875-887.

Yoon I, Kripke DF, Youngstedt SD \& Elliot JA. (2003). Actigraphy suggests age realted differences in napping and nocturnal sleep. J Sleep Res. 12(1), 87-93.

Youngstedt SD \& Kline CE. (2006). Epidemiology of exercise and sleep. Sleep Biol Rhythm. 4(1), 215-221.

Zagaar M, Alhaider I, Dao A, Levine A, Alkarawi A, Alzubadiy M \& Alkadhi K. (2011). The beneficial effects of regular exercise on cognition in REM sleep 
deprivation: behavioral, electrophysiological and molecular evidence.

Neurobiol Dis. 45(3), 1153-1162. 
APPENDIX A: Pittsburgh Sleep Quality Index

Subject's Initials: $\quad$ ID\#: $\quad$ Date: $\quad$ Time: $A M / P M$

\section{PITTSBURGH SLEEP QUALITY INDEX}

Instructions: The following questions relate to your usual sleep habits during the past month only. Your answers should indicate the most accurate reply for the majority of days and nights in the past month. Please answer all questions.

1. During the Past month, what time have you usually gone to bed at night?

BED TIME

2. During the pas month, how long (in minutes) has it usually taken you to fall asleep each night?

NUMBER OF MINUTES

3. During the past month, what time have you usually gotten up in the morning? GETTING UP TIME

4. During the past month, how many hours of actual sleep did you get at night? (This may be different than the numbers of hours you spent in bed.)

HOURS OF SLEEP PER NIGHT

\section{For each of the remaining questions, check the one best response. Please answer all questions.}

5. During the past month, how often have you had trouble sleeping because you...

a) Cannot get to sleep within 30 minutes

\begin{tabular}{l|l|l|l}
$\begin{array}{l}\text { Not during the } \\
\text { past month }\end{array}$ & $\begin{array}{l}\text { Less than } \\
\text { once a week }\end{array}$ & $\begin{array}{l}\text { Once or twice a } \\
\text { week }\end{array}$ & $\begin{array}{l}\text { Three or more } \\
\text { times a week }\end{array}$ \\
\hline & & &
\end{tabular}

b) Wake up in the middle of the night or early morning 


\begin{tabular}{l|l|l|l} 
Not during the & Less than & $\begin{array}{l}\text { Once or twice a } \\
\text { week }\end{array}$ & $\begin{array}{l}\text { Three or more } \\
\text { times a week }\end{array}$ \\
\hline & once a week & &
\end{tabular}

c) Have to get up to use the bathroom

\begin{tabular}{l|l|l|l} 
Not during the & Less than & $\begin{array}{l}\text { Once or twice a } \\
\text { week }\end{array}$ & $\begin{array}{l}\text { Three or more } \\
\text { times a week }\end{array}$ \\
\hline once a week & & &
\end{tabular}

d) Cannot breathe comfortably

\begin{tabular}{l|l|l|l} 
Not during the & Less than & $\begin{array}{l}\text { Once or twice a } \\
\text { week }\end{array}$ & $\begin{array}{l}\text { Three or more } \\
\text { times a week }\end{array}$ \\
\hline & once a week & &
\end{tabular}

e) Cough or snore loudly

\begin{tabular}{l|l|l|l} 
Not during the & Less than & $\begin{array}{l}\text { Once or twice a } \\
\text { week }\end{array}$ & $\begin{array}{l}\text { Three or more } \\
\text { times a week }\end{array}$ \\
\hline & once a week & &
\end{tabular}

f) Feel too cold

\begin{tabular}{l|l|l|l} 
Not during the & Less than & $\begin{array}{l}\text { Once or twice a } \\
\text { week }\end{array}$ & $\begin{array}{l}\text { Three or more } \\
\text { times a week }\end{array}$ \\
\hline once a week & & &
\end{tabular}

g) Feel too hot 


\begin{tabular}{l|l|l|l} 
Not during the & Less than & $\begin{array}{l}\text { Once or twice a } \\
\text { week }\end{array}$ & $\begin{array}{l}\text { Three or more } \\
\text { times a week }\end{array}$ \\
\hline & once a week & &
\end{tabular}

h) Had bad dreams

\begin{tabular}{l|l|l|l} 
Not during the & Less than & $\begin{array}{l}\text { Once or twice a } \\
\text { week }\end{array}$ & $\begin{array}{l}\text { Three or more } \\
\text { times a week }\end{array}$ \\
\hline & once a week & &
\end{tabular}

i) Have pain

\begin{tabular}{l|l|l|l} 
Not during the & Less than & $\begin{array}{l}\text { Once or twice a } \\
\text { week }\end{array}$ & $\begin{array}{l}\text { Three or more } \\
\text { times a week }\end{array}$ \\
\hline & once a week & &
\end{tabular}

j) Other reason(s), please describe

How often during the past month have you had trouble sleeping because of this?

\begin{tabular}{l|l|l|l}
$\begin{array}{l}\text { Not during the } \\
\text { past month }\end{array}$ & $\begin{array}{l}\text { Less than } \\
\text { once a week }\end{array}$ & $\begin{array}{l}\text { Once or twice a } \\
\text { week }\end{array}$ & $\begin{array}{l}\text { Three or more } \\
\text { times a week }\end{array}$ \\
\hline & & &
\end{tabular}

6. During the past month, how would you rate your sleep quality overall?

$$
\begin{aligned}
& \text { Very good } \\
& \text { Fairly good } \\
& \text { Fairly bad } \\
& \text { Very bad }
\end{aligned}
$$


7. During the past month, how often have you taken medicine to help you sleep (prescribed or "over the counter")?

\begin{tabular}{l|l|l|l} 
Not during the & Less than & $\begin{array}{l}\text { Once or twice a } \\
\text { week }\end{array}$ & $\begin{array}{l}\text { Three or more } \\
\text { times a week }\end{array}$ \\
\hline once a week & & &
\end{tabular}

8. During the past month, how often have you had trouble staying awake while driving, eating meals, or engaging in social activity?

\begin{tabular}{l|l|l|l} 
Not during the & Less than & $\begin{array}{l}\text { Once or twice a } \\
\text { week }\end{array}$ & $\begin{array}{l}\text { Three or more } \\
\text { times a week }\end{array}$ \\
\hline & once a week & &
\end{tabular}

9. During the past month, how much of a problem has it been for you to keep up enough enthusiasm to get things done?

No problem at all

Only a very slight problem

Somewhat of a problem

A very big problem

10. Do you have a bed partner or room mate?

No bed partner or room mate

Partner/room mate in other room

Partner in same room, but not same bed

Partner in same bed

If you have a room mate or bed partner, ask him/her how often in the past month you have had...

a) Loud snoring

\begin{tabular}{l|l|l|l} 
Not during the & Less than & $\begin{array}{l}\text { Once or twice a } \\
\text { week }\end{array}$ & $\begin{array}{l}\text { Three or more } \\
\text { times a week }\end{array}$ \\
\hline & once a week & &
\end{tabular}


b) Long pauses between breaths while asleep

\begin{tabular}{l|l|l|l}
$\begin{array}{l}\text { Not during the } \\
\text { past month }\end{array}$ & $\begin{array}{l}\text { Less than } \\
\text { once a week }\end{array}$ & $\begin{array}{l}\text { Once or twice a } \\
\text { week }\end{array}$ & $\begin{array}{l}\text { Three or more } \\
\text { times a week }\end{array}$ \\
\hline & & &
\end{tabular}

c) Legs twitching or jerking while you sleep

\begin{tabular}{l|l|l|l}
$\begin{array}{l}\text { Not during the } \\
\text { past month }\end{array}$ & $\begin{array}{l}\text { Less than } \\
\text { once a week }\end{array}$ & $\begin{array}{l}\text { Once or twice a } \\
\text { week }\end{array}$ & $\begin{array}{l}\text { Three or more } \\
\text { times a week }\end{array}$ \\
\hline & & &
\end{tabular}

d) Episodes of disorientation or confusing during sleep

\begin{tabular}{l|l|l|l}
$\begin{array}{l}\text { Not during the } \\
\text { past month }\end{array}$ & $\begin{array}{l}\text { Less than } \\
\text { once a week }\end{array}$ & $\begin{array}{l}\text { Once or twice a } \\
\text { week }\end{array}$ & $\begin{array}{l}\text { Three or more } \\
\text { times a week }\end{array}$ \\
\hline & & &
\end{tabular}

e) Other restlessness while you sleep; please describe

\begin{tabular}{l|l|l|l}
$\begin{array}{l}\text { Not during the } \\
\text { past month }\end{array}$ & $\begin{array}{l}\text { Less than } \\
\text { once a week }\end{array}$ & $\begin{array}{l}\text { Once or twice a } \\
\text { week }\end{array}$ & $\begin{array}{l}\text { Three or more } \\
\text { times a week }\end{array}$ \\
\hline & & &
\end{tabular}




\section{APPENDIX B: Sleep-Wake Journal}

\section{WAKE-UP DIARY}

1. What day is today?

\begin{tabular}{|l|l|l|l|l|l|l|}
$\mathrm{M}$ & $\mathrm{T}$ & $\mathrm{W}$ & $\mathrm{TH}$ & $\mathrm{F}$ & $\mathrm{S}$ & $\mathrm{SU}$ \\
\hline & & & & & &
\end{tabular}

2. What time did you got to bed last night? (Also mark AM/PM)

\begin{tabular}{|l|l|}
$\mathrm{AM}$ & $\mathrm{PM}$ \\
\hline &
\end{tabular}

HOUR

\begin{tabular}{|l|l|l|l|l|l|l|l|l|l|l|l|}
1 & 2 & 3 & 4 & 5 & 6 & 7 & 8 & 9 & 10 & 11 & 12 \\
\hline & & & & & & & & & & &
\end{tabular}

MINUTES

\begin{tabular}{|l|l|l|l|l|l|l|l|l|l|l|l|}
0 & 5 & 10 & 15 & 20 & 25 & 30 & 35 & 40 & 45 & 50 & 55 \\
\hline & & & & & & & & & & &
\end{tabular}

3. Did you feel ready for sleep when you went to bed?

\begin{tabular}{|l|l|} 
Yes & No \\
\hline &
\end{tabular}


4. Did you take anything to help you sleep? If yes, specify

\begin{tabular}{|l|l|} 
Yes & No \\
\hline &
\end{tabular}

5. How long did it take to fall asleep?

HOURS

\begin{tabular}{|l|l|l|l|l|}
0 & 1 & 2 & 3 & $4+$ Hours \\
\hline & & & &
\end{tabular}

MINUTES

\begin{tabular}{|l|l|l|l|l|l|l|l|l|l|l|l|}
0 & 5 & 10 & 15 & 20 & 25 & 30 & 35 & 40 & 45 & 50 & 55 \\
\hline & & & & & & & & & & &
\end{tabular}

6. How long were you awake during the night after you fell asleep?

\section{HOURS}

\begin{tabular}{|l|l|l|l|l|}
0 & 1 & 2 & 3 & $4+$ Hours \\
\hline & & & &
\end{tabular}

MINUTES

\begin{tabular}{|l|l|l|l|l|l|l|l|l|l|l|l|}
0 & 5 & 10 & 15 & 20 & 25 & 30 & 35 & 40 & 45 & 50 & 55 \\
\hline & & & & & & & & & & &
\end{tabular}

7. How many times did you wake up during the night?

\begin{tabular}{|l|l|l|l|l|l|l|l|l|l|l|l|}
0 & 1 & 2 & 3 & 4 & 5 & 6 & 7 & 8 & 9 & More
\end{tabular}




\begin{tabular}{|l|l|l|l|l|l|l|l|l|l|} 
& & & & & & & & & \\
than 9 \\
times
\end{tabular}

8. How long did you sleep last night?

HOUR

\begin{tabular}{|l|l|l|l|l|l|l|l|l|l|l|l|l|l|}
0 & 1 & 2 & 3 & 4 & 5 & 6 & 7 & 8 & 9 & 10 & 11 & 12 & $\begin{array}{l}\text { More } \\
\text { than } \\
12 \\
\text { hours }\end{array}$ \\
\hline & & & & & & & & & & & & &
\end{tabular}

MINUTES

\begin{tabular}{|l|l|l|l|l|l|l|l|l|l|l|l|}
0 & 5 & 10 & 15 & 20 & 25 & 30 & 35 & 40 & 45 & 50 & 55 \\
\hline & & & & & & & & & & &
\end{tabular}

9. Rate the quality of your sleep last night. (1=excellent; $5=$ poor $)$

\begin{tabular}{|l|l|l|l|l|}
1 & 2 & 3 & 4 & 5 \\
\hline & & & &
\end{tabular}

10. What time did you wake up to start your day? (Also mark AM/PM)

\begin{tabular}{|l|l|}
$\mathrm{AM}$ & $\mathrm{PM}$ \\
\hline &
\end{tabular}

HOUR 


\begin{tabular}{|l|l|l|l|l|l|l|l|l|l|l|l|}
1 & 2 & 3 & 4 & 5 & 6 & 7 & 8 & 9 & 10 & 11 & 12 \\
\hline & & & & & & & & & & &
\end{tabular}

MINUTES

\begin{tabular}{|l|l|l|l|l|l|l|l|l|l|l|l|}
0 & 5 & 10 & 15 & 20 & 25 & 30 & 35 & 40 & 45 & 50 & 55 \\
\hline & & & & & & & & & & &
\end{tabular}

11. What time did you get out of bed? (Also mark AM/PM)

\begin{tabular}{|l|l|}
$\mathrm{AM}$ & $\mathrm{PM}$ \\
\hline &
\end{tabular}

HOUR

\begin{tabular}{|l|l|l|l|l|l|l|l|l|l|l|l|}
1 & 2 & 3 & 4 & 5 & 6 & 7 & 8 & 9 & 10 & 11 & 12 \\
\hline & & & & & & & & & & &
\end{tabular}

MINUTES

\begin{tabular}{|l|l|l|l|l|l|l|l|l|l|l|l|}
0 & 5 & 10 & 15 & 20 & 25 & 30 & 35 & 40 & 45 & 50 & 55 \\
\hline & & & & & & & & & & &
\end{tabular}

12. How did you wake up?

\begin{tabular}{|l|l|l|} 
Spontaneously & Planned (e.g. alarm) & Unplanned disruption \\
\hline & &
\end{tabular}

13. How many alarms or prompts did you need to wake up? 


\begin{tabular}{|l|l|l|l|l|l|}
0 & 1 & 2 & 3 & 4 & More than 4 \\
\hline & & & & &
\end{tabular}

14. How difficult was it to wake up? (1-very easy;5=very hard)

\begin{tabular}{|l|l|l|l|l|}
1 & 2 & 3 & 4 & 5 \\
\hline & & & &
\end{tabular}

15. How alert do you feel now? ( $1=$ wide awake; $5=$ very sleepy $)$

\begin{tabular}{|l|l|l|l|l|}
1 & 2 & 3 & 4 & 5
\end{tabular}

16. How rested/refreshed do you feel now? $(1=$ very rested; $5=$ not at all $)$

\begin{tabular}{|l|l|l|l|l|}
1 & 2 & 3 & 4 & 5 \\
\hline & & & &
\end{tabular}

17. Comments:

\section{BEDTIME DIARY}

1. What day is today?

\begin{tabular}{|l|l|l|l|l|l|l|} 
M & T & W & TH & F & S & SU \\
\hline & & & & & &
\end{tabular}

2. For each of the pairs below, mark the response that best describes how you felt overall today. 


\begin{tabular}{|l|l|l|l|l|l|l|} 
Happy & 1 & 2 & 3 & 4 & 5 & Sad \\
\hline Tense & 1 & 2 & 3 & 4 & 5 & Relaxed \\
\hline Sleepy & 1 & 2 & 3 & 4 & 5 & Alert \\
\hline $\begin{array}{l}\text { Even } \\
\text { tempered }\end{array}$ & 1 & 2 & 3 & 4 & 5 & Mood swings \\
\hline Irritable & 1 & 2 & 3 & 4 & 5 & Easy going \\
\hline $\begin{array}{l}\text { Poor } \\
\text { concentration }\end{array}$ & 1 & 2 & 3 & 4 & 5 & $\begin{array}{l}\text { Good } \\
\text { concentration }\end{array}$ \\
\hline Tired & 1 & 2 & 3 & 4 & 5 & Energetic \\
\hline Worried & 1 & 2 & 3 & 4 & 5 & Care free \\
\hline Calm & 1 & 2 & 3 & 4 & 5 & Jittery
\end{tabular}

3. If you felt intensely sleepy or dozed off or fell asleep today without planning to, mark below every hour this occurred.

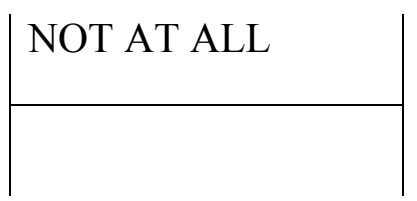

\begin{tabular}{|l|l|l|l|l|l|l|l|l|l|l|l|l|l|} 
NOON & 12 & 1 & 2 & 3 & 4 & 5 & 6 & 7 & 8 & 9 & 10 & 11 & $(\mathrm{pm})$ \\
\hline & & & & & & & & & & & & \\
\hline
\end{tabular}
\begin{tabular}{|l|l|l|l|l|l|l|l|l|l|l|l|l|l|} 
MIDNIGHT & 12 & 1 & 2 & 3 & 4 & 5 & 6 & 7 & 8 & 9 & 10 & 11 & $(\mathrm{am})$ \\
\hline
\end{tabular}

4. During which of these activities did you doze? Mark all that apply.

\begin{tabular}{|l|l|l|l|l|l|l|l|}
$\begin{array}{l}\text { Reading/ } \\
\text { studying }\end{array}$ & $\begin{array}{l}\text { Watching } \\
\text { TV/movie }\end{array}$ & Driving & $\begin{array}{l}\text { Morning } \\
\text { class }\end{array}$ & $\begin{array}{l}\text { Afternoon } \\
\text { class }\end{array}$ & $\begin{array}{l}\text { Evening } \\
\text { class }\end{array}$ & $\begin{array}{l}\text { At } \\
\text { work }\end{array}$ & NONE \\
\hline & & & & & & &
\end{tabular}

Other: 
5. Did you experience physical discomfort today? Mark all that apply.

\begin{tabular}{|l|l|l|l|l|l|} 
Headache & $\begin{array}{l}\text { Cold/allergy } \\
\text { symptoms }\end{array}$ & $\begin{array}{l}\text { Muscle/joint } \\
\text { pain }\end{array}$ & $\begin{array}{l}\text { Stomach } \\
\text { upset } \\
\text { symptoms }\end{array}$ & $\begin{array}{l}\text { Menstrual } \\
\text { cramps }\end{array}$ & NONE \\
\hline & & & &
\end{tabular}

$\square$ Other:

6. Did you taken any medications (including over-the-counter) today?

\begin{tabular}{|l|l|} 
YES & NO \\
\hline &
\end{tabular}

If yes, specify:

7. How many planned naps did you have today?

\begin{tabular}{|l|l|l|l|l|}
0 & 1 & 2 & 3 & $3+$ \\
\hline & & & &
\end{tabular}

8. How long was your longest nap?

$\mid$ NO NAP

HOUR

\begin{tabular}{|l|l|l|l|l|}
0 & 1 & 2 & 3 & $4+$ Hours \\
\hline & & & &
\end{tabular}

MINUTES

\begin{tabular}{|l|l|l|l|l|l|l|l|l|l|l|l|}
0 & 5 & 10 & 15 & 20 & 25 & 30 & 35 & 40 & 45 & 50 & 55 \\
\hline & & & & & & & & & & &
\end{tabular}

9. What time did this nap start? (Also mark AM/PM) 


\begin{tabular}{l|l|}
$\mathrm{AM}$ & $\mathrm{PM}$ \\
\hline &
\end{tabular}

HOUR

\begin{tabular}{|l|l|l|l|l|l|l|l|l|l|l|l|}
1 & 2 & 3 & 4 & 5 & 6 & 7 & 8 & 9 & 10 & 11 & 12 \\
\hline & & & & & & & & & & &
\end{tabular}

MINUTES

\begin{tabular}{|l|l|l|l|l|l|l|l|l|l|l|l|}
0 & 5 & 10 & 15 & 20 & 25 & 30 & 35 & 40 & 45 & 50 & 55 \\
\hline & & & & & & & & & & &
\end{tabular}

10. How much time did you nap today? (planned PLUS unplanned)

HOUR
\begin{tabular}{|l|l|l|l|l|}
0 & 1 & 2 & 3 & $4+$ Hours \\
\hline & & & &
\end{tabular}

MINUTES

\begin{tabular}{|l|l|l|l|l|l|l|l|l|l|l|l|}
0 & 5 & 10 & 15 & 20 & 25 & 30 & 35 & 40 & 45 & 50 & 55 \\
\hline & & & & & & & & & &
\end{tabular}

11. How many caffeine drinks (e.g. Coke, tea, coffee, etc.) did you have today? Morning (before noon)

\begin{tabular}{|l|l|l|l|l|l|}
\hline 0 & 1 & 2 & 3 & 4 & $5+$ \\
\hline & & & & &
\end{tabular}

\begin{tabular}{|l|l|l|l|l|l|}
\hline 0 & 1 & 2 & 3 & 4 & $5+$ \\
\hline & & & & &
\end{tabular}

Evening (after 6 pm) 


\begin{tabular}{|l|l|l|l|l|l|}
0 & 1 & 2 & 3 & 4 & $5+$ \\
\hline & & & & &
\end{tabular}

12. How many drinks of alcohol did you have today?

\begin{tabular}{|l|l|l|l|l|l|l|l|l|l|l|}
0 & 1 & 2 & 3 & 4 & 5 & 6 & 7 & 8 & 9 & $9+$ \\
Drinks
\end{tabular}

13. If you had vigorous physical activity for at least 15 minutes today, mark below every hour this occurred.

$\mid$ NONE

\begin{tabular}{|l|l|l|l|l|l|l|l|l|l|l|l|l|l|} 
NOON & 12 & 1 & 2 & 3 & 4 & 5 & 6 & 7 & 8 & 9 & 10 & 11 & $(\mathrm{pm})$ \\
\hline & & & & & & & & & & & & &
\end{tabular}

\begin{tabular}{|l|l|l|l|l|l|l|l|l|l|l|l|l|l|} 
MIDNIGHT & 12 & 1 & 2 & 3 & 4 & 5 & 6 & 7 & 8 & 9 & 10 & 11 & (am) \\
\hline & & & & & & & & & & & & &
\end{tabular}

14. How much time were you exposed to daylight in the first two hours after waking up today?

HOURS

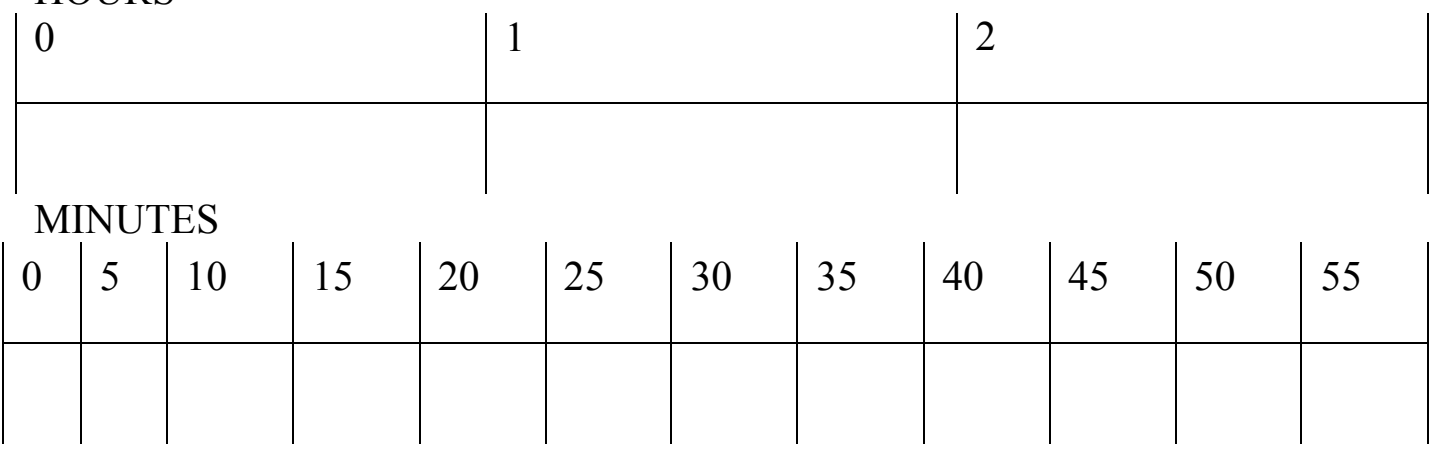

15. Comments: 
APPENDIX C: Accelerometer Testing

\section{Second Shake Test}

For the purpose of this test we selected a researcher who was right handed

\begin{tabular}{|l|l|l|l|l|l|}
\hline $\begin{array}{l}\text { Accelerometer } \\
\text { Placement }\end{array}$ & $\begin{array}{l}\text { Time } \\
\text { (Seconds) }\end{array}$ & $\begin{array}{l}\text { Step } \\
\text { count } \\
\text { (before } \\
\text { shake) }\end{array}$ & $\begin{array}{l}\text { Step } \\
\text { count } \\
\text { (after } \\
\text { shake) }\end{array}$ & $\begin{array}{l}\text { Actual } \\
\text { shakes/steps } \\
\text { (Video) }\end{array}$ & $\begin{array}{l}\text { Accuracy } \\
\text { (Step } \\
\text { count/actual } \\
\text { shakes) } x \text { 100 }\end{array}$ \\
\hline $\begin{array}{l}\text { Dominant } \\
\text { Hand- Right } \\
\text { Hand }\end{array}$ & & & & & \\
\hline
\end{tabular}

\section{Step Test}

Determine dominant foot (Subject closes their eyes for three second and will be pushed lightly from behind. The foot that comes forward is the dominant foot and will be used for measurement.)

\begin{tabular}{|l|l|l|l|l|}
\hline $\begin{array}{l}\text { Accelerometer } \\
\text { Placement }\end{array}$ & Steps Taken & $\begin{array}{l}\text { Step count } \\
\text { (before) }\end{array}$ & $\begin{array}{l}\text { Step count } \\
\text { (after) }\end{array}$ & $\begin{array}{l}\text { Accuracy } \\
\text { (Step count/ } \\
\text { steps taken) } x \\
\mathbf{1 0 0}\end{array}$ \\
\hline $\begin{array}{l}\text { Midline of } \\
\text { thigh, dominant } \\
\text { foot (right foot) }\end{array}$ & 20 & & & \\
\hline
\end{tabular}

\section{Treadmill 1 minute}




\begin{tabular}{|l|l|l|l|l|l|l|}
\hline $\begin{array}{l}\text { Accelerometer } \\
\text { Placement }\end{array}$ & $\begin{array}{l}\text { Time } \\
\text { (Seconds) }\end{array}$ & Speed & $\begin{array}{l}\text { Step } \\
\text { count } \\
\text { (before } \\
\text { walk) }\end{array}$ & $\begin{array}{l}\text { Step } \\
\text { count } \\
\text { (after } \\
\text { walk) }\end{array}$ & $\begin{array}{l}\text { Actual } \\
\text { steps } \\
\text { (Video) }\end{array}$ & $\begin{array}{l}\text { Accuracy } \\
\text { (Step } \\
\text { count/actual } \\
\text { steps) } \mathbf{x ~ 1 0 0 ~}\end{array}$ \\
\hline $\begin{array}{l}\text { Midline of } \\
\text { thigh, dominant } \\
\text { foot (right foot) }\end{array}$ & & $80 \mathrm{mpm}$ & & & & \\
\hline
\end{tabular}


APPENDIX D: Self-Administered Rating Scale for Pubertal Development

Introduction: The next questions are about changes that may be happening to your body. These changes normally happen to different young people at different ages. Since they may have something to do with your sleep patterns, do your best to answer carefully. If you do not understand a question or do not know the answer, just mark "I don't know."

Question

1. Would you say that your growth in height:
Response Options

has not yet begun to spurt ${ }^{2}$

has barely started

is definitely underway

seems completed

I don't know
Point Value

1

2

3

4

has not yet begun to grow

1

has barely started to grow

2

is definitely underway

3

seems completed

4

I don't know

3. Have you noticed any skin changes, skin has not yet started changing 
especially pimples?

\section{FORM FOR BOYS:}

4. Have you noticed a deepening of your voice? skin has barely started changing

skin changes are definitely

underway

skin changes seem complete

I don't know
2
5. Have you begun to grow hair on your face?

$\begin{array}{ll}\text { voice has not yet started changing } & 1 \\ \text { voice has barely started changing } & 2 \\ \text { voice changes are definitely } & 3 \\ \text { underway } & \\ \text { voice changes seem complete } & 4 \\ \text { I don't know }\end{array}$
facial hair has not yet started
1
growing
facial hair has barely started
2
growing
facial hair growth has definitely
3
started
facial hair growth seems complete
4
I don't know

3

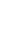

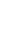


breasts have begun to grow?

underway

breast growth seems complete

I don't know

5a. Have you begun to menstruate yes (started to have your period)?

no

$5 b$. If yes, how old were you when you started to menstruate? age in years 


\section{CURRICULUM VITAE}

\section{AMY WALDEN}

215 Beech Grove Road

Shepherdsville, KY 40165

C: (502) $249-6829$

Ajwald04@gmail.com

DOB: 07/20/1992

Citizenship: USA

\section{EDUCATION}

Masters of Science, Exercise Physiology

Expected date of graduation:

May 2016

University of Louisville - Louisville, KY

Concentration: Strength and Conditioning, GPA

Bachelor of Science: Health and Human Performance

May 2014

University of Louisville - Louisville, KY

Double Concentration: Exercise Science and Public Health

Cum Laude, 3.5 GPA

\section{POSITIONS AND HONORS}

Graduate Assistant

$08 / 2014$ to

Current

University of Louisville - Louisville, KY

- Teaching exercise fitness classes and assisting in laboratory courses

- Scheduling and conducting exercise fitness testing

High Intensity Interval Field Hockey Trainer

$07 / 2015$ to

10/2015

Male High School - Louisville, KY

- Co-creating a high intensity training regime for field hockey athletes

- Instructing proper form and adequate trainer for a varsity, junior varsity and freshmen team

\section{Health Fitness Specialist}

Health Fitness General Electric - Louisville, KY

- Teach physical activity classes to athletic club members

- Conduct personal fitness assessments on new clientele to determine an appropriate workout regime to fit their goals

\section{Research Assistant}

$08 / 2013$ to

05/2014

Frazier Rehabilitation Institute - Louisville, KY

- Develop protocol for testing spinal cord injury population in body composition study utilizing skinfolds and anthropometric measures

- Aiding in data collection and analyzing of lab data 
Resources for Academic Achievement - University of Louisville

- Connecting students with recognized student organizations to improve retention rates at the University of Louisville

- Providing assistance for students of low socioeconomic class an alternate perspective that encourages them to succeed

Cochran Elementary School Program Director

$08 / 2010$ to

08/2011

AmeriCorp Bonner Leaders - Louisville, KY

- Classroom aide to students with math and science skills

- Coordinated manner programs and presentations for fourth and fifth grade classrooms

- Formed reading groups for students not meeting grade level requirements

\section{PROFESSIONAL EXPERIENCE/OUTREACH}

Louisville Sport Performance Institute

to $\mathbf{5 / 2 0 1 5}$

Lead children training session and instructed movement patterns in adults

Cards for Kids Internship

08/2011 to

$05 / 2012$

Coordinated children education tours and revamped disability awareness materials for the center

Alternative Spring Break Black Mountain, NC

03/2012 Provided support with local farms and educating local students on importance of healthy eating

\section{PRESENTATIONS}

Poster Presentation - CoAuthor $2^{\text {nd }}$ place in Undergraduate research

05/2015

Neuroscience Day at Frazier Rehabilitation Institute

Poster Presentation

03/2014

National Conference on Undergraduate Research (NCUR) on Spinal Cord Injury testing protocol

Poster Presentation

$04 / 2012$

Undergraduate Research Symposium on Black Mountain, NC on

farming techniques

\section{PAST RESEARCH INVOLVEMNT:}

- Effects of Locomotor Training on Trunk Postural Control and Respiratory Function in Children with Spinal Cord Injury, IRB: 13.0361

- Metabolic Function and Oxygen Consumption in Individuals with Spinal Cord Injury, IRB:

12.0400

- Validation of Anthropometric Measurements and Estimates of Body Composition in Standard, Sitting and Supine Positions, IRB: 12.0335

- The effects of sport-specific training conditions, sleep quality and physical; activity levels on performance in high school field hockey players, IRB: 15.0415

- Validation of a mouthguard usage and satisfaction questionnaire- a pilot study, IRB: 15.0529

\section{PEER - REVIEWED ARTICLES}


Terson de Paleville, D., Lorenz, D., McCulloch, J., Aslan, S., Kloby, M., Love, M., Walden, A., \& Harkema, S. (2014). Development of protocols to estimate maximal oxygen consumption and body composition in individuals with spinal cord injury. The FASEB Journal. 28(1), Supplement 884.27.

\section{PROFESSIONAL MEMEBERSHIP}

Six Sigma Green Belt Training

10/2015

Precision Nutrition Certification Level 1

10/2015

ACSM Certified Exercise Physiologist

$10 / 2015$

National Federation of High School Coaches Certification

10/2015

Peer Mentoring Level 2, Certification

05/2013

University of Louisville Leadership, Certification

Received

05/2012 